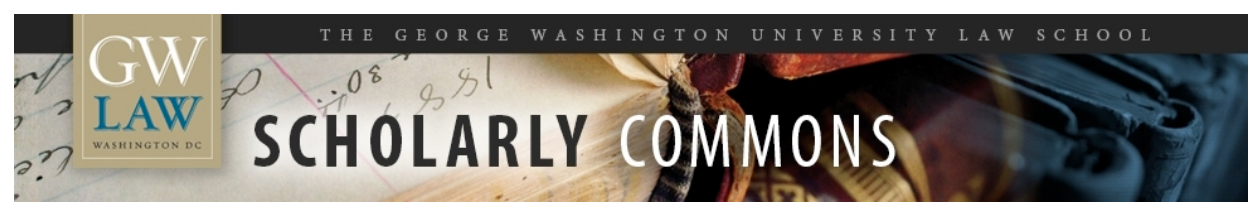

\title{
From Pluralism to Individualism: Berle and Means and 20th- Century American Legal Thought
}

Dalia Tsuk Mitchell

George Washington University Law School, dtsuk@law.gwu.edu

Follow this and additional works at: https://scholarship.law.gwu.edu/faculty_publications

Part of the Law Commons

\section{Recommended Citation}

30 Law \& Soc. Inquiry 179 (2005)

This Article is brought to you for free and open access by the Faculty Scholarship at Scholarly Commons. It has been accepted for inclusion in GW Law Faculty Publications \& Other Works by an authorized administrator of Scholarly Commons. For more information, please contact spagel@law.gwu.edu. 


\section{From Pluralism to Individualism: Berle and Means and 20th-Century American Legal Thought}

\section{Dalia Tsuk}

Adolf A. Berle, Jr., and Gardiner C. Means. The Modern Corporation and Private Property. New York: Macmillan, 1932. Pp. 409.

\section{INTRODUCTION}

"The rise of the modern corporation," Adolf A. Berle and Gardiner C. Means wrote in the last paragraph of The Modern Corporation and Private Property (1932), "has brought a concentration of economic power which can compete on equal terms with the modern state." In the future, they predicted, the corporation could even supersede the state "as the dominant form of social organization." "The law of corporations," Berle and Means concluded, "might well be considered as a potential constitutional law for the new economic state, while business practice is increasingly assuming the aspect of economic statesmanship" (p. 357).

The Modern Corporation and Private Property was one of the earliest attempts to connect the growth of giant corporations with the political and social changes occurring in a rapidly growing industrialized society. Seven decades later, Berle and Means's prophecy rings true. The rapid economic, social, and technological changes of the 20th century have led to the emergence of large corporate bureaucracies. As national governments amass political power, multinational corporations dominate the global economy,

Dalia Tsuk is Associate Professor of Law at The George Washington University Law School. For comments on earlier drafts she thanks Larry Mitchell and Arthur Wilmarth. 
"over which ... centralized national governments have less and less control" (Genovese 1997, 202).

Surprisingly, in the collective imagination of corporate law scholars, The Modern Corporation and Private Property, which remains one of the most cited works in recent decades (Bratton 2001, 738), is remembered not as the book that called attention to corporate power, but as the book that called attention to the separation of ownership from control in large public corporations.' Legal scholars turn to the book's exegesis of the phenomenon of the separation of ownership from control to justify the shareholder-centered vision of managerial duties, most famously expressed by Milton Friedman, according to which corporate managers are agents of shareholders and must manage the corporation in ways that maximize the profits of their principals, to the exclusion of the interests of other corporate constituencies or the community at large $(1962,133-36 ; 1970)$.

How did Berle and Means's somber comparison between corporate power and government power disappear from the scholarly imagination? The answer to this question reaches beyond the boundaries of corporate law. As I argue in this essay, The Modern Corporation and Private Property was inspired by a particular collectivist tradition that immensely influenced the development of American law in the first part of the 20th century, only to be replaced by an individualist approach in the years following World War II. So long as this collectivist approach, which I label legal pluralism, ${ }^{2}$ informed analyses of corporate law (and law more broadly), references to The Modern Corporation and Private Property emphasized the need to constrain corporate

1. Most recently, William Bratton explained that the legacy of The Modem Corporation and Private Property has been its rigorous study of the growing separation of ownership from control. According to Bratton, the history of the book's exegesis of the separation of ownership from control had two stages. In the first 50 years after its publication, the book was "the basis of a paradigm that dominated the field"-it focused on managerial fiduciary duties as a solution to the problem of separation of ownership from control. Beginning in the early 1980s, however, "the book lost its paradigmatic position along with the general collapse of confidence in regulatory solutions to economic problems." Instead of focusing on managerial duties, contractarianism-the new paradigm - viewed corporations as nexuses of contractual arrangements between rational actors, a vision that undermined the need for regulation (2001, 737). On contractarianism, see E. Weiss 1984; Butler 1989; Columbia Law Review 1989; Easterbrook and Fischel 1991; Brudney 1997.

Nonetheless, according to Bratton, the transformation from managerialism to contractarianism did not lessen the significance of the book's legacy. Despite harsh critiques of the book's data and of its inaccurate prediction of "ever increasing concentration and dispersion of property," the book's exposition of the difficulties associated with the separation of ownership from control has remained the focus of corporate scholarship throughout the 20th century. Even contractarians have argued that the separation of ownership from control causes agency costs to be suboptimally high, and hence jeopardizes contractual self-regulation (75456). On agency costs, see Coffee 1989, 1674-76; J. Gordon 1989, 1577; Butler and Ribstein 1990.

2. In anthropological and sociological studies the term legal pluralism is often used to describe the multiplicity of normative centers or institutions in society. In legal studies, the federal system is described as committed to the idea of legal pluralism. I use the term in reference to corporations, not only because it reflects the mindset of the historical actors discussed 
power through external mechanisms (like federal regulation). The separation of ownership from control was seen through this prism: It allowed corporations to amass economic and political power, and it undermined the traditional assumption that (individual) self-interest was the best constraint on the use of corporate power. Once legal scholars embraced an individualist interpretation of corporate law, the rights of individual participants in the corporate endeavor - first consumers and workers, but later shareholdersbecame the focus of attention. By the 1980 s, mainstream corporate law scholars insisted that corporations were to be regulated from within-through shareholders' exercise of their power to vote or, more important, their power to sell their shares. In this context, The Modern Corporation and Private Property became a book about the economic risks (especially to investors) triggered by the separation of ownership from control, about the role of the free market in ameliorating them, and about the ways in which law should imitate the free-market solutions.

This essay is divided into three parts. The first part explores Berle and Means's vision as they articulated it and as their contemporaries understood it. I argue that The Modern Corporation and Private Property embraced a legal pluralist vision of the modern state. It rested on the assumption that collective institutions like labor unions and corporations were constitutive elements of American society and therefore had to be dealt with if the American democratic experiment were to continue to succeed. This assumption was first explicated by a group of political theorists known as political pluralists. Legal pluralists added a dimension of power to theories of political pluralism. They called attention to the fact that collective institutions were not only constitutive elements of the modern state, but also centers of political and economic power equivalent to the power of the state. Indeed, legal pluralists argued that the rapid growth of collective institutions challenged the liberal assumption that power was embedded in the state. They sought to articulate legal doctrine to allow collective institutions to exercise their (public) power, while limiting potential excesses and abuses of power. ${ }^{3}$

In short, for Berle and Means the important message of the book was a political argument about the allocation of power in society, particularly

in this essay, but also because I believe that we ought to think about corporations as normcreating and norm-enforcing institutions. While the corporation's power to enforce its rule is different from the power of the sovereign state to do so, the corporation's economic, social, and cultural impact has become so pervasive in modern sociery so as to make corporate power, in effect, comparable to the coercive power of the state.

3. This early-20th-century pluralist vision shared with the more well-known postwar pluralism assumptions about the dispersal of power among diverse groups. Yet, while postwar pluralist theories tended to assume that power could be mediated through neutral political and economic markets, early-20th-century pluralists saw group power as equivalent to sovereign power, and hence as unchecked by political and economic markets. On the similarities and differences hetween early-20th-century theories of political pluralism and postwar pluralism, see Eisenberg 1995. On the differences and similarities between political and legal pluralism, see Tsuk 2003. 
the allocation of power between the state and a wide range of collective institutions. Accordingly, the separation of ownership from control not only enabled large collective institutions to amass coercive power (which could not be tamed by self-interest), but also pointed to means of constraining corporate power. Berle and Means argued that just as the breakup of the property atom allowed corporations to accumulate and exercise power of the magnitude of state power, it also undermined traditional assumptions about the protection of property rights and justified subjecting corporations to the limitations associated with sovereign power-that is, the requirement that their power be exercised to benefit the community at large. The Modern Corporation and Private Property thus concluded with Berle and Means's proclamation that the power of large economic organizations, as augmented by the separation of ownership and control, should be exercised to satisfy the demands of the community. Corporate power was a power in trust for society.

By insisting that the power of collective institutions had to be exercised to promote social welfare, Berle and Means drew a balance between decentralization and centralized planning that many legal pluralists, especially those who joined the New Deal administration, found appealing. Within a year of its publication date, The Modern Corporation and Private Property became the economic bible of many New Deal programs, the thrust of which was to coordinate the works of large economic organizations through administrative agencies. Programs as different as securities regulation, the Tennessee Valley Authority, and the National Recovery Administration sought to ameliorate the failing (Depression) market by creating cooperative programs among business, labor, consumers, and the government.

But the legal pluralist image of the modern state was short-lived, as was Berle and Means's vision of the corporation. The second part of this essay traces how in the course of the 20th century, Berle and Means's message about corporate power and the allocation of power in society, more broadly, disappeared from the scholarly imagination.

I begin by examining how by the 1940s, a wide range of factors helped shift the attention of lawyers, legal scholars, and government officials from collective entities to the individual as the basis for legal and political analysis. Growing critiques of New Deal policies prompted intellectuals to turn to the market (and away from the state) as a regulatory mechanism. At the same time, increasing apprehension about the politically contagious European totalitarianism turned scholarly attention to individual rights. Gradually, a conception of a free market, constrained only by constitutional limitations on the power of collective institutions (especially over individuals), replaced the 1930s administrative, legal pluralist approach as a means of regulating corporate power. In this context, too, interest group pluralism replaced legal pluralism as the dominant group theory. Using models of equilibrium drawn from economics, interest group pluralists sought to create a 
conception of a neutral political process in which different groups interact, compete, or trade ends (Horwitz 1992, 251-58; Tsuk 2003, 1905-8).

In corporate law, the shift from collectivism to individualism was initially reflected in a gradual shift from regulatory to constitutional limitations on corporate power. The Modern Corporation and Private Property continued to be viewed as a book about corporate power, but scholars began to elaborate other ways to constrain such power. Specifically, instead of demanding that corporate power be exercised in trust for the community, scholars emphasized the need to subject corporate power to the constitutional limitations embedded in the Bill of Rights. This shift was reflected in Adolf Berle's own writings in the 1950s and 1960s (1952, 1954, 1967a).

As the third part explicates, ultimately, the scholarly focus on individual rights as a means of regulating corporate power helped legitimate a very different picture of the modern corporation-one that described corporate entities as nexuses of private, contractual relationships. Informed by neoclassical economics, advocates of this new theory of the firm emphasized the role of economic markets in regulating corporate power. In their hands, the scholarly focus on individual rights, in fact entitlements, as a means of constraining corporate power was gradually translated into a shareholder-wealthmaximization vision of corporate law.

First, to accommodate their picture of the corporation, and their deregulatory vision of the state, proponents of the new economic theory of the firm sought to refute earlier concerns about corporate power (Bratton 1989a, 1478-82). With deregulation and free markets in mind, they reread The Modern Corporation and Private Property to be a book not about corporate power, but about the limited question of the effects of the separation of ownership from control on efficiency and profit maximization. ${ }^{4}$ Then, having described Berle and Means and their disciples as concerned with efficiency rather than power, advocates of the new economic theory of the firm announced that the problem, truly, was not a problem. Specifically, they argued that investors preferred to remain passive as it allowed them to maximize their profits through diversification, that both the controlling group and the shareholders shared the same interests (namely, the maximization of profits), and that the market (for shares) held the controlling group at bay. Given such assumptions (or conclusions), the separation of ownership from control did not pose a problem, but rather pointed to the appropriate legal regime: Law was assigned the limited role of mimicking private arrangements intended to maximize profits (including keeping shareholders passive and self-interested),

4. Many have described this question of efficiency and profit maximizing under the label "agency costs"-that is, the costs involved in "structuring, monitoring, and bonding a set of contracts among agents with conflicting interests" (Fama and Jensen 1983b, 304). Early law and economics scholarship often dismissed the problem of agency costs as corrected by the free market, but more recently, law and economics scholars have admitted its endurance and sought to devise legal rules that would ameliorate it. 
and a market ethics fixated on the short-term maximization of shareholders' wealth, the results of which we saw in the corporate scandals of the early-21st century, became legitimated (Mitchell 2001).

By uncovering the relationship between the rise and fall of a pluralist image of the modern state and the transformation of corporate law in the 20th century, this essay challenges traditional narratives about corporations and the rise of the administrative state. For one thing, it demonstrates that the legal image of the modern corporation was not a necessary outcome of rapid industrialization or of economic culture that bounded scholars' imagination, ${ }^{5}$ but rather the outcome of attempts by legal scholars to promote particular ideologies. Progressives sought not only to expose, but also to embrace, multiple centers of coercive power. Their corporate law emerged out of a deliberate attempt to analogize, for purposes of regulatory policies, corporate authority and responsibility to sovereign powers and liabilities. In turn, corporate legal scholarship at the turn of the 21 st century is dominated (with a few exceptions) by an individualist ideology, which often dismisses concerns about power and the need for regulation.

Moreover, by using the transformation of corporate law as illustrative of the development of American legal thought in the 20th century, this essay revives a particular jurisprudential tradition that has thus far been ignored-legal pluralism. As I begin to demonstrate, legal pluralism was a midway position between the ideologies of decentralization and centralization that sociologists and political scientists have come to associate with the rise of the modern welfare state. ${ }^{6}$ For one thing, legal pluralists assumed that corporations could not be efficiently regulated by local or state institutions, or by strong national regulation. Instead, pluralists sought to subject large economic organizations to the constraints associated with limits on governmental power. Not only did their approach offer an alternative for the centralized state we have come to associate with the New Deal, it was also imprinted upon a variety of legal doctrines. ${ }^{7}$

By using The Modern Corporation and Private Property as a way to begin exploring the legal pluralist image of the state, I hope this essay not only offers an alternative way to reconceptualize corporations and the state, but also opens up a door for future studies about the different sites of sovereign power that characterize our society and how their existence impacts our

5. For example, Mark Roe explicated how the separation of ownership from control was not a necessary or natural progression of industrialized societies, but rather a development peculiar to American democratic culture (1994).

6. On nationalization and decentralization as positions in the political debates of the early-20th century, see Skowronek 1982; Fraser and Gerstle 1989; Sandel 1998, 211-227.

7. This essay draws on a larger project in which I examine the development of theories of pluralism in the 20th century, the interdependence of the different meanings attributed to pluralism in distinct historical moments, and the relationship between theories of pluralism and the emergence of the modern welfare state. For other parts of the narrative, see Tsuk $2001 \mathrm{a}, 2001 \mathrm{~b}, 2002 \mathrm{a}, 2003$. 
understanding of diverse legal rules and doctrines. While we continue to determine the boundaries of power between local, state, national, and international governments (under categories such as decentralization, nationalization, and globalization), we must also critically assess how the development of nongovernmental centers of power has often occurred unchecked, away from public scrutiny.

\section{PART I: 1932-THE MODERN CORPORATION, PRIVATE PROPERTY, AND THE LEGAL PLURALIST VISION OF THE MODERN STATE}

\section{Berle and Means on Corporations, Property, and Power}

In 1962, Berle commented that in 1932, the year that The Modern Corporation and Private Property was published, "the book was thought so dangerous as to be almost worth suppressing": "It was in fact first brought out by a law-publishing house then affiliated with the Corporation Trust Company. Discovering the viper they had nourished in their corporate bosom, publication was promptly suspended after a few copies had been sold.... Shortly after, the book was reissued by Macmillan" (434).

Writing three decades after the events, Berle explained that the book was thought to be "so dangerous" because it challenged the "power system" (434). Interestingly, this characteristic also made it very appealing to lawyers, economists, historians, and the popular press. In a review, Jerome Frank predicted that "this book would perhaps rank with Adam Smith's Wealth of Nations as the first detailed description in admirably clear terms of the existence of a new economic epoch" $(1933,989)$. In a similar manner, Charles Beard wrote that "in the time to come this volume might be proclaimed as the most important work bearing on American statecraft between the publication of the immortal 'Federalist' by Hamilton, Madison and Jay and the opening of the year 1933" (B. Berle and Jacobs 1973, 22; Hessen 1983, 273).

The project was conceived in 1927, when Berle obtained a research grant from the Social Science Research Council (financed by the Laura Spelman Rockefeller Foundation). As the grant required the research to "be carried on in connection with some recognized university," Berle-a young New York lawyer, who was known for a series of commentaries on the separation of ownership and management in large corporations-joined the Columbia Law School faculty (becoming a full professor in 1928, upon William Douglas's resignation). As the grant further stipulated that Berle was "to study corporations with an economist," Berle asked Means--a friend and an economics graduate student - to be his collaborator (B. Berle and Jacobs 1973, 20-21; Schwarz 1987, 50-52; Bratton 2001, 752-53). Berle 
and Means then recruited research students in law and in economics to help with the detailed statistical and economic study:

For example, one year was spent by the research law students on corporate bonds, each student, or group of students, writing on some new problem in that field. Another year was spent on consolidation, mergers and dividends, and the last year on the legal phases of corporate accounting. Thus in a short time there has been assembled a mass of data that would take a single economist a lifetime to gather and digest. (Kilne 1933, 558)

The statistical studies, which Means supervised, documented the growing dispersion of stock ownership in large corporations and, hence, the rapid separation of ownership from control (Means's contribution was primarily in the first chapters, which contained about 40 pages of charts and tables [Hessen 1983, 274-75]). Berle and Means concluded that the separation of ownership from control "produc[ed] a condition where the interests of owner and of ultimate manager ... often ... diverg[ed], and where many of the checks which formerly operated to limit the use of power disappear[ed]" (p. 6).

Specifically, Berle and Means argued that the divergence between the interests of owners and those of the control group severed the tie between self-interest and efficiency. In the classical model of market relations, individuals owned and controlled the means of production, and competition between individual entrepreneurs was presumed to result in efficient distribution of market sources. Self-interest-" "held in check only by competition and the conditions of supply and demand"- -was seen as "the best guarantee of economic efficiency." The separation of ownership from control in large public corporations challenged this assumption. Corporate managers, who "own[ed] so insignificant a fraction of the company's stock," had no incentive to increase the corporation's value. In turn, stockholders, "to whom the profits of the corporation went, could not be motivated by those profits to a more efficient use of the property, since they [had] surrendered all disposition of it to those in control of the enterprise." Berle and Means concluded that, as a consequence, the managerial use of shareholders' property might be both self-interested and inefficient. "It raises for reexamination the question of the motive force back of industry, and the ends for which the modern corporation can be or will be run," they wrote (p. 9; Hessen 1983, 276).

One would be mistaken, however, to assume that for Berle and Means (and their contemporaries), the contribution of The Modern Corporation and Private Property was its rigorous analysis of the separation of ownership from control. ${ }^{8}$ Indeed, in 1932 , the book's novelty was its normative

8. Certainly, Berle and Means were not the first scholars to call attention to the separation of ownership from control in large corporations. Throughout the early decades of the 20th century, Progressive legal scholars expressed concerns about management's growing 
message. ${ }^{9}$ For Berle and Means, the "separation of control from ownership" was troubling not merely because it broke the atom of property, but also, and more important, because at the same time that it undermined self-interest as a regulatory tool, it "[made] possible tremendous aggregations of property." For one thing, Means's statistical studies illustrated that some 200 corporations, controlled by fewer than 1,800 men, administered over one-third of the national wealth (p. 5; Bratton 2001, 752-53). The possibility of mass concentration of power augmented the risk of inefficient uses of power, which could adversely affect the economy at large. ${ }^{10}$ The power that corporations could amass and ways to tame it became the book's underlying theme.

Power was an "elusive concept, for power could rarely be sharply segregated or clearly defined" (p. 69). As Scott Bowman explained, Berle (and Means) described two dimensions of power: an internal dimension and an external one $(1996,207)$. The internal dimension focused on the power of corporations over individuals within them, specifically power over employment decisions: "[T]he relation of the corporation to its workers, its plant organization and its technical problem of production" (p. 7). The external dimension emphasized corporations' impact on society at large, specifically corporations' power to control markets by administering prices, their capacity to accumulate capital and affect the economy, and their ability to shape the forces of production through the development of new technology (p. 7; Bowman 1996, 207-8). Both dimensions of power underlay Berle and

power and shareholders' inability to control it. In a 1910 address, Woodrow Wilson noted the relatively weak position of stockholders, especially in comparison to the power of those in control. According to Wilson, shareholders did not enjoy any of the rights associated with property in connection with their corporate stock; they merely contributed money to a business, which other men managed and controlled (434; Frank 1933, 990). In 1923, Thorstein Veblen explored the development of the modern corporate structure, arguing that "absentee ownership [had] come to be the main and immediate controlling interest in the life of civilized men" (3). In 1925, Thomas Carver pointed out the increasing dispersal of corporate securities (Isaacs 1933, 463). In 1927, William Ripley argued that shareholders in publicly held corporations had become powerless (78-99; Hessen 1983, 279; Stigler and Friedland 1983, 241). And in 1931, Maurice Wormser described the corporation as "Frankenstein's creature [which] had developed into a deadly menace to his creator" (Isaacs 1933, 464).

9. Jerome Frank, for example, described the book as the "[f]irst detailed description [of] a new economic epoch," during which corporate rulers had become "princes who ... are sovereigns subject to no effective legal checks." Following Berle and Means, Frank concluded that such transformation raised important questions as to the appropriate restraints on corporate power (1933, 989-96). In a similar manner, Isaacs emphasized Berle and Means's attention to the social consequences of the separation of ownership from control $(1933,464)$.

10. Because Berle and Means's argument focused on publicly held corporations (which Berle labeled quasi-public), they viewed the consolidation of power and the separation of ownership from control as interrelated phenomena. As they put it: "The Fords and the Mellons, whose personal wealth is sufficient to finance great enterprises, are so few, that they only emphasize the dependence of the large enterprise on the wealth of more than the individual or group of individuals who may be in control" (p. 5). On Berle and Means's failure to separate the two phenomena, see McCraw 1990, 584. 
Means's proclamation that the corporation's economic power resembled the power of the sovereign state; hence, it could not be curbed by the state. $^{11}$

Having called attention to corporate power, as augmented by the separation of ownership from control, Berle and Means began to formulate a unified theme for the law of corporations. They evaluated three ways to guarantee responsible exercises of power. The first way-the application of strict property rules to passive ownership-would have required the control group to exercise corporate power for the "sole benefit of the security owners." Berle and Means feared that such rules would have "the bulk of American industry ... operated by trustees for the sole benefit of inactive and irresponsible security owners." The second way-application of strict contractual rules-would have invested in the control group uncurbed powers and seen security holders as having "agreed in advance to any losses which they might suffer by reason of such use." Berle and Means believed that such rules would create "a corporate oligarchy coupled with the probability of an era of corporate plundering." Rather than choosing traditional rules of property or contracts as the underlying theme of the modern law of corporations, Berle and Means settled on a third alternative; it "offer[ed] a wholly new concept of corporate activity" (pp. 354-56).

Specifically, Berle and Means argued that shareholders, "by surrendering control and responsibility over the active property, [had] surrendered the right that the corporation should be operated in their sole interest,they [had] released the community from the obligation to protect them to the full extent implied in the doctrine of strict property rights." But this tampering with the interests of the owners did not make the controlling group the beneficiary of corporate power. Rather, Berle and Means concluded that if the separation of ownership from control was a problem, it also pointed to the solution. Specifically, it had "cleared the way for the claims of a group far wider than either the owners or the control." It had "placed the community in a position to demand that the modern corporation serve not alone the owners or the control [group] but all society" (pp. 355-56):

Should the corporate leaders, for example, set forth a program comprising fair wages, security to employees, reasonable service to their public, and stabilization of business, all of which would divert a portion of the profits from the owners of passive property, and should the community generally accept such a scheme as a logical and human solution of industrial difficulties, the interests of passive property owners would have to give way. (p. 356, emphasis added)

11. For more on Berle's distinction between economic and political power, see Bowman $1996,214-17$. 
Simply put, The Modern Corporation and Private Property announced that (because ownership was separated from control) publicly held business corporations were public trustees. Their power was to be exercised to satisfy the demands of the community, however these were to be defined.

\section{Berle and Means in Context: Legal Pluralism}

Berle and Means's analysis of corporate power drew upon the Progressives' reconceptualization of property rights as a delegation of coercive power to individuals. According to Progressive legal scholars (and their followers, the legal realists), the distinction between a supposedly noncoercive private sphere of individual rights and a coercive public sphere of state regulation was fundamentally misguided, because all relations among private parties were premised on the existence and enforcement of the laws of contracts and property by the state. Private law was thus a form of regulatory public law. Property rights were a means by which the government compelled some to yield an income to the owners. And the supposedly self-executing market was a social construct that reflected prevailing judgments as to policy, justice, right and wrong, which were often subconscious and inarticulate (Hale 1923; Cohen 1927; Singer 1988, 487-94; Horwitz 1992, $193-$ 212; R. Gordon 1995; Alexander 1997, 243-302; Tsuk 2002b). In this vein, Berle and Means argued that because property-especially corporate property (which did not even resemble traditional property) - was a means by which the state legitimated the use of nongovernmental coercive power, the state could require those in control of such power to promote public interests (Horwitz 1992, 166; Alexander 1997, 342-46; Bratton 2001, 760-61).

Yet the issue at stake was not only one of property rights but also one of government. Indeed, by highlighting the relationship between property and power, Berle and Means also helped reshape a particular, legal pluralist vision of the modern state. The interconnections between legal pluralism and The Modern Corporation and Private Property made the book's legacy an enduring one.

The legal pluralist vision is traceable to theories of political pluralism that developed in Britain and the United States amidst the organizational revolution of the early-20th century. ${ }^{12}$ Political pluralists argued that because

12. The term organizational revolution is used to imply that the rise of large business corporations at the turn of the 20th century encouraged other groups to pursue their interests through collective action, bureaucratic structures, and administrative expertise. As Ellis Hawley pointed out, "the land that had idealized yeoman farmers and rugged individualists was becoming a land of corporate organization, bureaucratic systematizers, and associational activities" $(1979,9)$. While the term organizational revolution refers to American society in the early-20th century, groups and associations had always played an important role in American life. The classic account of the role of associations in the antebellum era remains Tocqueville 1835-40. For more recent accounts, see Novak 1996; O'Melinn 2000. 
individuals organized into groups to pursue their interests, groups and organizations were centers of participation and representation. They maintained that by exploring the role of groups in society, they could offer a more realistic description of liberal democratic politics and of the (limited) role of the liberal state (Bentley 1908, 465-80; Latham 1952, 12-13). Furthermore, for many political pluralists, making groups and collective institutions the basis for political and social analysis was not only a means of achieving a more accurate description of American society at the turn of the 20 th century, but also a normative vision. For them, the state, taken as a whole, was too broad and abstract a body to command loyalty and allegiance from individuals, who associated more easily with diverse groups and organizations than with a unified state entity. They not only recognized the existence of a multiplicity of centers of self-government in society, but also endorsed this multiplicity as a constitutive element of American democracy. They encouraged the growth of associations to facilitate the flourishing of valuable forms of identities, ways of life, experiences, and viewpoints, all of which were necessary to enable individuals to live rich and meaningful lives (Laski 1917; Follett 1918; Dewey 1927). ${ }^{13}$

While they encouraged the growth of collective institutions, pluralists were also very concerned about the power that collective institutions could amass. In fact, potential abuses and excesses of power were the core of the pluralist dilemma - that is, the need to determine the normative limits of a commitment to pluralism. On the one hand, political pluralists recognized the significant role of associations, such as churches, political parties, neighborhood groups, corporations, and trade unions in an industrialized society, either as promoters of individual autonomy and protectors of individuals against an otherwise omnipotent state or as economic bases for democracy. Such assumptions supported deference to group authorities. To allow the state to exercise power over diverse groups risked imposing one set of concededly partial interests and beliefs in the name of a general public good. On the other hand, large organizations, such as corporations, could amass

13. For example, Harold Laski announced that "the pluralistic theory of the State ... insists that the State, like every other association, shall prove itself by what it achieves... [and] sets group competing against group in a ceaseless striving of progressive expansion" $(1917,23)$. In a similar manner, Mary Parker Follett-an active social worker and freelance writer, whose work on democracy has more recently begun to receive growing recognitionargued that "[g]roup organization is to be the new method in politics, the basis of our future industrial system, the foundation of international order ... for creative force comes from the group, creative power is evolved through the activity of the group life." "The new and true democracy," Follett explained, "was to be built from small neighborhood groups, to community groups, to state groups, to national group, and eventually to an international group "will' " (1918, 3 quoted in Wren 1987, 257-58). And John Dewey echoed Follett's argument by proclaiming that "democracy is not an alternative to other principles of associated life. It is the idea of community life itself" $(1927,148)$. For a historical and political analysis of American theories of pluralism, see Eisenberg 1995. For an examination of British theories of political pluralism, see Hirst 1989. 
great economic, political, and social power. Like the sovereign state, these organizations could threaten the rights of individuals subject to their power. Such assumptions seemed to justify normative intervention in the internal governance structures of corporations and other collective institutions, government intervention being seen as enhancing individual autonomy (Stewart 1987, 373; Ernst 1993, 60).

Some political pluralists assumed that corporations would remain relatively small, never amassing the power of the nation-state. For example, in his early works, Harold Laski, a British political theorist, uncritically adopted Louis Brandeis's claim that large business units would be "physically incapable of successful administration," and therefore that business corporations were "naturally limited in scope." Given such assumptions, Laski's early pluralist ideal justified liberating corporate management "from all restrictions imposed by a higher authority, whether that higher authority be the State, the shareholders or management's own recognition of sacred order." Laski genuinely believed that the "corporation, being a real entity, with a personality that is self-created and not state-created must bear the responsibility for its actions." Yet he neglected to assess to whom corporate responsibilities extended, or who would keep corporations in check (1916; Friedlander 1996, 89-94). "Having pointed to 'interests,'” R. Jeffrey Lustig has charged, pluralists "failed to analyze empirically how those interests were structured in particular configurations" $(1982,142-43){ }^{14}$

A different political pluralist solution focused on the relationship between management and workers in corporations. For example, Mary Parker Follett, an American political theorist, advocated the organization of work to assure that the experience of workers would be integrated with the experience of the expert controlling the plant. Industrial democracy, she wrote, would emerge out of the integrative experience of labor and management (1924). Follett urged management to exercise power with workers, not over them (1925); she envisioned management and labor working together to solve conflicts in an "integrative" way-by accommodating the demands of all parties involved through cooperation rather than competition (Graham $1995,21-24) .^{15}$

14. Influenced by his interactions with American scholars, especially Morris Raphael Cohen, who admonished the pluralists' deference to corporate authorities, Laski altered his initial position, turning to solutions that resembled those advocated by legal pluralists (1918, 1925). On Laski's later renunciation of the analogy between individual personality and the personality of associations, see Schneiderman 1998, 532-33.

15. Immersed in Boston's social welfare projects, in particular Boston's public schools, Follert lectured on different occasions, publicizing her particular interpretation of industrial democracy. She worked with the Placement Bureau and the Vocational Guidance Bureau in Boston and was a member of the Massachusetts Minimum Wage Board. Follett was also a conference leader of the Bureau of Personnel Administration in New York (Metcalf and Urwick 1942). 
While political pluralists trusted corporate size, workers, or managerial statesmanship to constrain corporate power (Lustig 1982, 114-15; Barenberg $1993,1422-23$ ), it remained the task of legal pluralists to articulate laws and policies that would embrace corporate power while simultaneously taming its potential abuses. By the 1920 s, they helped shift the focus of debates about pluralism away from identity and self-governance as the centerpieces of the modern state to the potentials and risks of group power.

In this vein, Berle and Means embraced corporations as constitutive elements of the modern industrial society (McCraw 1990, 582), and analyzed them not only as private business enterprises, but also as social and political institutions, involving "the interrelation of a wide diversity of economic interests, - those of the 'owners' who supply capital, those of the workers who 'create,' those of the consumers who give value to the products of enterprise, and above all those of the control who wield power" (pp. 352-53). But in this vein, too, Berle and Means also viewed corporations-with their multiplicity of owners, financial complexity, managerial control, and immortality-as centers of real, potentially coercive power in society. Corporate structure resembled government structure. Corporate financial capacities resembled sovereign economic powers. Like government authorities, corporate managers exercised power by means of a rationalized system of control and administration. Like the sovereign state, large corporations formulated laws and policies affecting individuals and groups. Like states, corporations were social, economic, and political entities.

Given the similarities between the corporation and the state, Berle and Means wanted to focus intellectual attention on corporate power. They argued that the separation of ownership from control allowed tremendous buildups of power, and that given corporations' economic power, it was meaningless to assume that corporations were private associations, or that the state was the only center of coercive (public) power. Accordingly, corporations were not private contractual arrangements, as liberal legal theory sought to describe them, but rather law-making and law-applying entitiescenters of coercive economic power, which was "comparable to the concentration of religious power in the medieval church or of political power in the national state" (p. 352). "A Machiavelli writing today would have very little interest in princes, and every interest in the Standard Oil Company of Indiana," Berle and Means proclaimed shortly before the publication of The Modern Corporation and Private Property (1930, 71).

Because they celebrated the contributions of corporate power to the modern industrial society, Berle and Means feared that an overuse of government regulation could eliminate potential benefits of corporate power. Like other pluralists, they realized the need to encourage the development of diverse collective institutions to promote various experiences and actions. Because they feared potential abuses of corporate power, they 
also rejected the idea of freeing corporations to act as if they were mere aggregates of individuals or real entities, distinct from their individual members. ${ }^{16}$ They rejected both the early pluralists' scheme of self-governing associations, ${ }^{17}$ and the alternative of allowing the state to regulate all corporate activities.

Instead, Berle and Means drew on the reconceptualization of sovereignty as distributive rather than collective and sought to subject large economic organizations to limits associated with checks on government power, specifically the requirement that corporations act to benefit the community. ${ }^{18}$ Large corporations, they wrote, were best conceptualized as "the organized activity of vast bodies of individuals, workers, consumers and suppliers of capital under the leadership of the dictators of industry, 'control"' (p. 349). It was thus conceivable, if not essential, that "the 'control' of the great corporations should develop into a purely neutral technocracy, balancing a variety of claims by various groups in the community and assigning to each a portion of the income stream on the basis of public policy rather than private cupidity" (p. 356).

16. For most of the 19 th century, corporations were viewed as artificial entities, created by a charter or a grant of the state. By the late-19th century, however, the fiction paradigm lost much of its credibility as states encouraged incorporation in their territories by reducing the requirement for a state charter into a mere formality. To accommodate the change, legal thinkers adopted either a contractual vision or a natural entity one. The contractual paradigm described corporations as mere associations of individuals, similar to partnerships. In turn, the natural or real entity paradigm portrayed corporations as distinct from their individual members, though like them they had a real existence. Ultimately, the natural/real entity vision won over corporate legal theory. In part, its success was due to the inability of the contractual paradigm to accommodate the dramatic changes in business structure at the turn of the 20th century. Specifically, the contractual paradigm seemed to ignore the recognized truth that ownership in large public corporations was rapidly separated from control; in other words, as individual corporators were not responsible for corporate actions, corporations could not be described merely as aggregations of shareholders' property. Indeed, even those who did not envision the corporation as a natural entity described its existence as real. They used the real entity paradigm pragmatically - it was becoming an accurate description of corporate reality, with its multiplicity of ownership, complex financial structure, managerial control, and immortality. When Berle and Means turned to study corporations, the debate was thus settled: corporations were real entities. For more on the different visions of the corporation, see Mark 1987; Hager 1989; Millon 1990; Horwitz 1992, 65-107; Tsuk 2003, 1870-75.

17. Compare, for example, Berle's early works to The Modern Corporation and Private Property. In his first book, Studies in the Law of Corporations Finance (1928), Berle expressed views similar to those of political pluralists, suggesting that corporate power could be mediated through voluntary arrangements. Berle's analysis focused on three safeguards for investors: "An association of interested investment bankers, stock exchange regulation of markets, and the organized market power of institutional stockholders whose interests coincided with individual stockholders" (Schwarz 1987, 53; Berle 1928, 4-40). Faced with Means's statistical exploration of the rapid concentration of economic power, Berle's focus shifted from groups to group power as the basis for legal and political analysis.

18. It is important to stress the difference between the view that corporate power was analogous to sovereign power and the older, artificial vision of corporations as created by charters from the state. By analogizing corporate power to sovereign power, legal pluralists sought to emphasize that unchecked organizational power could compete with, if not supersede, the sovereign state. 
Berle and Means concluded that in the exercise of their power, corporations should be required to consider all interests and act to satisfy the needs of the community at large (though, as I argue below, Berle seemed to have been conflicted on the subject). They moved away from traditional, abstract distinctions between public and private entities, and in their place made power (sovereign, nongovernmental, coercive) the category of legal analysis. Berle and Means further argued that uses of corporate power should be subject to judicial scrutiny. Courts, accordingly, were to guarantee that corporations exercised their power in trust for the benefit of the community. Neither the shareholders nor the controlling group could deny this fundamental duty (pp. 274-75; Chayes 1960, 31; Bratton 2001, 765-66). Corporations were free to exercise their power-in trust, under the watch of law. ${ }^{19}$

Such was the legal pluralist message of The Modern Corporation and Private Property. Its focus was corporate power. The separation of ownership from control was important to the extent that it contributed to the amassing of corporate power and pointed to ways to tame potential excesses and abuses of corporate power. Berle and Means did not fully work out the details of their scheme. They did not elaborate what the trust responsibilities of corporations toward the community were. Nor did they explicate how courts would avoid imposing on various organizations and associations one set of beliefs endorsed by the sovereign state or how courts would formulate laws that would accommodate multiple viewpoints and experiences. ${ }^{20}$ In any event, as the following part explains, within a short decade after the publication of The Modern Corporation and Private Property, different social, political, and intellectual trends gradually eroded the legal pluralist image of the state and, ultimately, Berle and Means's important message.

19. While Berle and Means's turn to the judiciary might seem awkward given the New Dealers' general preference for administrative agencies over courts, it was nonetheless typical of Progressive corporate law writings, intended to provide flexibility in the assessment of community interests and the role of the corporation. For more on Progressive corporate law and the judiciary, see Bratton 2001.

20. In retrospect, Berle and Means's solution might seem as a rather monistic (antipluralistic) approach: The sovereign state, through its courts, was to impose its values on diverse associations. Accordingly, Betle and Means, who had described society as composed of multiple sovereigns, normatively gave in to monism and subjected all (sovereign) associations and organizations to the absolute sovereignty of the state. It is important to remember, however, that Berle and Means also believed that the sovereign state was required to exercise its power to promote the public good. In this context, Berle and Means's analogy between sovereign states and corporations and their assignment to the courts-and the rule of lawthe role of determining appropriate exercises of power by various associations and organizations (including the state) supported pluralism. Indeed, trusting the courts to develop legal doctrines to facilitate pluralism-rather than imposing on all corporations monolithic rules and requirements - seemed to be a perfect way out of the pluralist dilemma. It sought a balance-not a choice-between the polarities of group self-government and absolute sovereignty, hetween the demands of conservative individualism and radical collectivism. For more on this dilemma, see Ernst 1993. 


\section{PART II: 1930s-1960s-THE LEGAL PLURALIST VISION OF THE MODERN STATE, ECLIPSED}

\section{From a New Deal to World War}

Berle and Means's conception of self-governing corporations celebrated a diversity of economic activities and experiences. Yet by insisting that corporate power had to be exercised to promote social welfare, as defined by the courts, Berle and Means rejected a nonjudgmental, free-market attitude toward economic and political diversity. They offered a particular way out of the pluralist dilemma, drawing a balance between decentralization and centralized planning that many legal pluralists turned New Dealers found appealing. Specifically, by suggesting that power was and should be distributed among a wide range of collective institutions, which, in turn, were to be regulated by the courts' definition of the common good, Berle and Means moved beyond both Brandeis's attack on bigness and calls (such as Herbert Croly's) to nationalize the economy. They sought to balance decentralization with national planning, to re-create the decentralized communities in which Americans had traditionally exercised self-government while encouraging Americans to endorse a new, pluralistic understanding of their national identity.

Not all those who viewed groups as the bases of the modern state accepted the corporate model as the ultimate model for reform. Many political pluralists adopted a traditional, contractual, vision of groups and associations, as did many supporters of labor organization. They preferred to view labor unions as voluntary trade agreements meant to achieve better wages, hours, and working conditions and protected under the First and Thirteenth Amendments to the Constitution (Pope 2002). Still, by the time the New Deal administration came into power, the legal pluralists' collectivist approach and the labor organizers' contractual approach converged on viewing the collaboration among associations and collective entities under a national umbrella as a way out of the Depression. Groups and associations could protect individuals from the uncertainties of the market, while insuring against disasters that could sweep through a national economy.

Such hopes informed many New Deal programs. The Securities Act of 1933 and the Securities Exchange Act of 1934 rested on the assumption that government planning required cooperation with big business, and that mandatory transparency and disclosure had to underlie such cooperation. ${ }^{21}$

21. Already in The Modern Corporation and Private Property, Berle and Means wrote that "the securities [were] useful as a basis of credit or exchange throughout the country ... [and of ] ... information" (p. 299). Then, in The Nature of Difficulty (written for members of Franklin Roosevelt's "brain trust"), Berle reiterated his conclusions in The Modern Corporation and Private Property, urging the establishment of "a Capital Issues Board which could perform the functions of a federal Blue Sky Commission, exacting full information about securities sold." 
In a similar manner, the Tennessee Valley Authority, created in 1933, sought to combine government planning with a decentralized, regional bureaucracy. It offered a means of cultivating small, integrated communities where workers would remain attached to the land while gaining access to electricity, transportation, and technology. And, while according to some commentators, the National Industrial Recovery Act of 1933 erred on the side of extreme national planning, it, too, was rooted in the understanding that collective entities such as corporations and labor unions played an important role in the modern economy. The NIRA established the $\mathrm{Na}$ tional Recovery Administration (which the U.S. Supreme Court declared unconstitutional in 1935) to oversee cooperative programs among business, labor, and government (specifically to negotiate agreements with employers regarding working conditions and collective bargaining) (Sandel 1998, 25255). Not surprisingly, within a year after its publication, Time magazine labeled The Modern Corporation and Private Property "the economic Bible of the Roosevelt administration" (Hovenkamp 1988, 1685).

These programs were adopted during the first phase of the New Deal. Their main focus was bringing relief and recovery through government planning and coordination (Weiner 1952, 724-25). They were grounded in the realization that, as Louis Jaffe put it, "the most significant and powerful components of the social structure [were] economic groups, competing and complementary in varying degrees" $(1937,201)$; their thrust, as Means described it, was not to "make the market effective as a coordinator," which would have required "revers[ing] the trend of a century and break[ing] the large units into a multitude of smaller enterprises." Rather, the thrust of the early New Deal was to keep the large units and increase "the element of administrative coordination of economic activity rather than its elimination" $(1935,63)$.

Focused, as they were, on the collaboration between government and business, the early New Deal programs were informed by the legal pluralism of Berle and Means. Gradually, however, and especially after the unanticipated economic recession of 1937, New Dealers began to reassess their vision of the modern administrative state.

Some New Dealers advocated the expansion of the regulatory state. Many of them were consistently opposed to the idea of an associational economy (or pluralism), and the failure of the NRA to provide sufficient relief to the sick economy only exacerbated their belief that the attempt to create a "'business commonwealth' capable of ordering its own affairs ... had produced only increased concentrations of power and artificially inflated prices." They rejected the pluralists' belief in a harmonious industrial society

Berle hoped that such a commission would develop "to the point where it would exercise a real control over undue expansion of groups of credit instruments, where issue of these reached a point threatening the safety of the financial structure" (B. Berle and Jacobs 1973, 47). 
composed of multiple parts, organically tied together, and functioning with limited state interference, and instead argued that conflict and instability were inevitable in the modern economy. To alleviate these modern traits, they called on the federal government to "step into the market to protect the interests of the public." These New Dealers did not call for decentralization of economic power or stricter antitrust oversight. Rather, they wanted to expand the regulatory functions of the administrative state to defend the consumer and promote full production (Brinkley 1989, 87-94).

Protecting consumers and increasing mass purchasing power was also the focus of a second group of New Dealers who endorsed not a regulatory vision of the modern state but a compensatory one. For them, the plurality of large economic entities was both a real and a positive development. Hence, they wanted to guarantee that the state did not intervene in the activities of collective institutions. For them, the state's role was not to coordinate economic activity but to redress "weaknesses and imbalances in the private economy without directly confronting the internal workings of capitalism." The state was to "manage the economy without managing the institutions of the economy." As President Franklin Roosevelt pointedly put it, the government's role was to spend capital "to increase [the] public wealth and to build up the health and strength of the people," in order "to help [the] system of private enterprise to function" (Brinkley 1989, 94-97).

With totalitarianism in Europe, and scholars' growing concerns about the relationship between statism and tyranny (Brinkley 1995, 154-65), the compensatory, fiscal vision of the state, which invested only limited power in the state, became the more appealing one. At the same time, the economic boom produced by the war efforts made the need for regulation less urgent. The economy seemed to do well without government interference. A vision of a free market, compensated by the state's fiscal hand on rare occasions, began to dominate economic thought (Brinkley 1989, 97-121; Sandel 1998, 250-73). It was a swift revolution. Rapidly, large corporations took over government responsibilities. Writing in 1952, Berle noted that "[a]n immensely important area of American industrial and financial economy is administered in each field by 'concentrates,' composed of not more than five or six large corporations in each identifiable field" (641).

The corporation, however, had changed. By the end of the New Deal, as Herbert Hovenkamp wrote, "[l]ittle was left of the classical corporation": The federal securities acts regulated its relationship with shareholders and creditors, federal labor laws regulated its dealings with workers, while antitrust laws and the Federal Trade Commission regulated the corporation's relationship to consumers and suppliers (1988, 1688-89). Such transformations gave the corporation a legal appearance that was very different from the powerful entity described in The Modern Corporation and Private Property.

Indeed, while changes in corporate structure during the first half of the 20th century helped augment the power and discretion of corporate 
management, the New Deal regulatory tools helped obscure the economic (and political) risks associated with such power. In the aftermath of World War II, the lessening of concerns about corporate power converged with a growing uneasiness about the collectivist vision that legal pluralists embraced in the early-20th century to produce a new image of the state and of the corporation. As the following sections expiain, this vision put, first, individual rights and, then, individual entitlements at the center of legal, political, and economic analyses. Gradually, the early-20th-century pluralist vision that Berle and Means brought to bear upon corporate law was erased out of the scholarly imagination.

\section{The Individualist Turn}

Beginning in the late 1930s, different trends and developments helped shift the attention of American scholars away from collective institutions and toward the individual as the basis for legal and political analysis.

First among these developments was the wide acceptance of Keynesian economics beginning in the late 1930s and continuing until the mid-1970s. It provided economic justification for the later New Deal fiscal policies, which sought to regulate the economy not through planning but by "accepting existing consumer preferences" and "manipulating aggregate demand." As Michael Sandel recently explained, Keynesian economics was predicated upon the belief that governments should not choose among competing individual visions of the public good. Its celebration both reflected this image - the image of the night-watchman state-and helped deepen its hold on American public life. The individual consumer became the foundation of economic thought (1998, 251-62).

The individual was also at the core of a new pluralist image of the modern state, which political theorists, especially Robert Dahl, articulated in the postwar years. While informed by the early pluralists, Dahl and his colleagues reduced collective entities into individual arrangements (viewing collective institutions as allowing individuals more effectively to socialize and to pursue their ends). Drawing upon models of equilibrium derived from economics, their pluralist image of the state rested on the assumption that individuals formed multiple interest groups that interacted, competed, and traded ends in neutral economic and political markets $(1956,1967)$. Together these neopluralists turned the American state into a political compromise between diverse pressure groups and entrusted presumably free political markets to produce shared public goods (Purcell 1973, 253-66). ${ }^{22}$

22. On different strands of postwar interest group pluralism, see Eisenberg 1995; Schiller $1999,5-18$. 
The neopluralist image of the state was traceable to "a loss of faith in the ideals of laissez-faire capitalism," specifically the idea "that self-interest pursued in economic transactions would inure to the common good." Yet, ironically, neopluralists embraced a similar faith in the structure of political markets and political bargains. Accordingly, the public interest would result from "the unregulated pursuit of private interests in the legislatures" (Balkin 1990, 388-91).

Indeed, proponents of both Keynesian economics and interest-group politics hoped to create "a social order that was neither intrusive nor anarchistic, that provided opportunities for cooperative action and crevices for personal freedom" (Pells 1989, 143-44). John Kenneth Galbraith described the countervailing demands of different economic interests (producers, labor unions, consumers) as the fuel that made American capitalism work (1952, 115-39). And Daniel Bell noted that " $[\mathrm{t}]$ he growing complexity of society necessarily multiplie[d] ... interests, regional or functional, and in an open society the political arena ... [was] a place where different interests [fought] it out for advantage" $(1960,60)$. In short, postwar intellectuals viewed interest groups, organized along economic or political axes, as ensuring social, political, and economic stability (Glasberg and Schwartz 1983, 325).

Keynesian economics and the neopluralist vision of the state emphasized the role of the individual (consumer or group member), but they also retained a role for the group in economic and political analysis. Indeed, it was another strand of legal thought, emerging out of the same intellectual milieu, which had a more critical effect on legal pluralism's demise. Beginning in the late 1930s, constitutional law scholars made individual rights the focus of legal analysis. The New Deal administration endorsed an early-20th-century civil rights discourse, which emphasized the rights of individuals to work, to livelihood, to social insurance, and to economic independence. This vision of rights was compatible with collective rights. Beginning in the late 1930s, however, constitutional law scholars shifted attention from the rights of collective institutions such as labor unions to the rights of ethnic and racial minorities. Gradually, they helped shape a different discourse of rightsnamely, the right of the individual to be different (Forbath 2000, 698-99).

The new discourse of rights was nurtured by growing apprehension about the politically contagious European totalitarianism, increased African American organization and protest (among other issues, against labor unions' discriminatory practices), fears of Japanese propaganda directed at African Americans, and concerns about overzealous patriotism that during World War I manifested itself in encroachments upon civil liberties. Amidst anxiety about the possibility that totalitarianism would reach American shores, the issue of ethnic and racial equality eclipsed concerns about economic and social rights. Despite the strong correlation between racial discrimination and economic inequality, and the combined ascendance during the 1940s of both racial and labor-related rights, the concept of liberty became associated 
with the right not to suffer racial and ethnic discrimination and the concept of social and economic citizenship gradually lost its primacy (Forbath 2000, 707-8; Dudziak 2001; Goluboff 2001).

The shift from social and economic rights to racial and ethnic discrimination was paralleled by a change in the perception of the role of the three branches of government in protecting civil rights. Specifically, in the early-20th century, and most important during the New Deal, legal scholars emphasized the role of the executive and legislative branches in promoting social and economic rights. But with totalitarianism in Europe, as legal scholars became increasingly concerned about the relationship between statism and tyranny, they sought to limit governmental power. While neopluralists envisioned a passive legislature, merely giving voice to the desires of interest groups, scholars emphasizing individual rights sought to limit the control of the legislative and executive branches by strengthening the authority of the Supreme Court to protect individual rights and liberties; the Warren Court reflected the culmination of their efforts. ${ }^{23}$

It was this intellectual atmosphere-in which economists focused on the individual consumer, neopluralists on the individual group member, and constitutional law scholars on the right of individuals to be different-that led progressive legal thinkers to reject the collectivism (or pluralism) of earlier generations. For one thing, concerns about the power of the state grew into concerns about the potential power of other collective institutions, leading legal scholars and political theorists to turn their uninterrupted attention to the defense of individual rights and liberties. ${ }^{24}$ It is with this in mind that we can turn to a major milestone in the development of

23. In comparison, while they envisioned a passive legislature, neopluralists called for judicial restraint. Members of what had become known as the legal process school, including Alexander Bickel, Herbert Wechsler, Harry Wellington, Albert Sacks, and Henry Harr, maintained that "choices among policy preferences were best left to the politically responsive legislature." In their opinion, the judiciary was not to intervene with policymaking, but rather was required "to determine sociery's 'enduring values' and to ferret out 'neutral principles' upon which legislation should be judged." For example, the judiciary was to guarantee that legislative processes would not unfairly exclude certain groups, specifically African Americans (Schiller 1999, 13-16). This vision fell into disrepute in the 1960s (Tsuk 2003, 1908).

24. Powerful critiques pointed to the inequalities of social, political, and economic power that permeated American corporations and society. C. Wright Mills, for example, argued that in the postwar years, "a conjunction of historical circumstances has led to the rise of an elite of power," whose "decisions carry more consequences for more people than has ever been the case in the world history of mankind." According to Mills, the postwar years witnessed "[t]he top of the American system of power ... [becoming] much more unified and much more powerful, the bottom ... much more fragmented, and in truth, impotent" $(1956,28-29)$. Mills's contemporary, Henry Kariel, explicitly placed the blame for this outcome with the intellectuals' fascination with pluralism. He charged that American social science had provided the framework that allowed organizations to trump individual rights. Kariel advocated placing constraints on organizational practices to promote the protection of individual liberties (1961). As Kariel indicated, he would have the United States move "from the much-celebrated ideal of Tocqueville toward the still unfashionable one of Rousseau, from a hierarchical public order toward an equalitarian one" (4). Sharing similar views, Gabriel Kolko, Mills's and Kariel's contemporary, reinterpreted the regulatory laws of the Progressive era as reflecting the efforts 
the modern discourse of rights, and, thus, in the story of legal pluralism's demise-to Charles Reich's "The New Property" (1964).

"The New Property" was the most important article on the subject of property since the realists (Berle and Means among them) challenged the classical (natural rights) conception of property. Informed by the Keynesian economists' discussion of the role of the state, by the political theorists' discussion of interest groups, and by the legal scholars' growing obsession with the Bill of Rights, Reich introduced the idea of property as a basic entitlement. "[I]n the final analysis," he wrote:

... the Bill of Rights depends upon the existence of private property. Political rights presuppose that individuals and private groups have the will and the means to act independently. But so long as individuals are motivated largely by self-interest, their well-being must first be independent. Civil liberties must have a basis in property, or bills of rights will not preserve them. $(1964,771)$

Reich's goal was to protect individuals against abuses of government power, especially in the allocation of government benefits. He wanted his readers to recognize that government largesse-"money, benefits, services, contracts, franchises and licenses"-were replacing traditional forms of wealth (733). Drawing on the legal realists' critique of the distinction between a public sphere of coercive power and a private sphere of individual transactions, Reich attacked the traditional distinction between private, prepolitical property rights and public, governmentally created, privileges. If, as the realists demonstrated, all property was governmentally created, then, Reich proclaimed, the constraints on the allocation of private property should be applied to government largesse. Accordingly, the fact that government benefits were public property could not mean that such benefits could be withheld completely.

By characterizing government largesse as property, Reich hoped to establish procedural constraints that would bolster the welfare state while strengthening its rule of law character. He was reacting to the abuse of governmental power during the McCarthy era, specifically to denials of benefits to people accused of communist associations. Viewing "the role of the

of conservative corporate leaders to maintain the social and political status quo amidst changing economic conditions $(1963,8)$. Kolko pointedly proclaimed that the modern American state was the result of business efforts to explain capitalism in a way that allowed the corporate elite to maximize their profits (3). Kolko further emphasized that "many wellintentioned writers and academicians" ended up supporting business goals-not only because they naively believed that "Iglovernment economic regulation, per se, was desirable" or "assumed that the power of government was neutral and socially beneficent," but also because many of them were, in fact, conservative in their intentions, viewing the stability promoted by businesses as the only way to maintain "the basic virtues of capitalism" (286). On the role of these intellectuals in discrediting "the group pluralist vision of policy-making," see Schiller $1999,48-52$. 
new property, as well as the old," as satisfying "individuals' needs- not necessarily their wants-so that they can contribute to the commonwealth as independent citizens" 25 (Alexander 1997, 375), Reich sought to use procedural constraints to legitimate the welfare state. In so doing, however, he also undermined the conservative undertones of earlier critiques of the administrative state, critiques that called for procedural constraints on administrative agencies (Horwitz 1992, 245-46; Alexander 1997, 368-75).

Reich's "The New Property" was compatible with the legal pluralist vision of the state. Indeed, Reich recognized the significance of collective institutions. "Today," he commented, "it is the combined power of government and the corporation that presses against the individual" (1964, 773). Yet, unlike the pluralists who encouraged collective ownership while seeking to limit the power of collective entities, Reich's postwar critique of the public-private distinction used the liberal protection of private property to advocate the creation of individual entitlements in public (or collective) property. Instead of emphasizing that corporations were trustees for the community, Reich pointed out the need to allocate the benefits created by collective institutions (and the government) to individuals. It is thus perhaps not surprising that, despite Reich's goals, his theory was quickly interpreted as advocating the idea that "property is a negative claim that the owner has against others, including the state, not to interfere with her use, possession, and enjoyment of her property" (Alexander 1997, 373-75).

A concept of property associated neither with collective ownership nor with individual ownership but with entitlements-specifically individual entitlements - sat well with a description of liberty as the freedom to pursue individual interests away from government regulation. According to the libertarians' vision of the new property, the state's role was thus not to seek to provide individuals with a set of particular goods, but rather to protect individuals' entitlements and expectations. As part III of this essay explicates, in corporate law, stock and the expectancy of profits became such entitlements. Before exploring how the shift from pluralism to individualism became a shift from concerns about corporate power to concerns about shareholders' property rights, let us turn, first, to the legal pluralists' (specifically to Berle's) reinterpretation of their collectivist vision in an intellectual world committed to individual rights.

\section{The (Legal) Pluralist Alternative I: Corporations and the Bill of Rights}

For legal pluralists like Berle and Means, the protection of individual rights went hand in hand with, indeed complemented, the celebration of

25. In this respect, Reich belonged with the civic republican tradition, which examined property ownership as a means of allowing individuals to participate in the public sphere (Alexander 1997, 373-77). 
collective rights. While they did not fully work out the details of the balance between collective and individual rights, pluralists sought to empower individuals by recognizing the importance of collective institutions to individual freedom and by allowing individuals to come together, to unite, to promote their interests. Potential tensions between the individual and the group were mediated, as The Modern Corporation and Private Property illustrated, by constraints on group power. In other words, at the same time that pluralists encouraged the growth of collective institutions, they also believed they could tame the power that such entities could exercise over individuals (and other groups).

This legal pluralist vision continued to influence legal scholarship in the postwar years. For example, Mark DeWolfe Howe, a professor at Harvard Law School, emphasized the advantages of extending rights to groups. Robert Horn, a political scientist at Stanford University, encouraged the Supreme Court to protect groups "both from government interference and from the atomistic tendencies of individuals who claimed rights against a group." And Thomas Cowan, a professor of law at Rutgers University, criticized American courts for ignoring the fact that "modern life [was] lived associatively. The new democracy [was] an aggregation of sub-groups, not primarily of individuals." Indeed, many other postwar legal scholars, following in the tradition of legal pluralism, studied the possible ways in which the law could accommodate different groups and promote pluralism (Schiller 1999, 17).

Such was Berle's mindset. Continuing to support government planning, but refusing to view corporations as mere aggregations of shareholders (or property owners), Berle called attention to the importance of subjecting corporations to constitutional limitations as if they were state actors. Specifically, Berle proclaimed that in the course of the first half of the 20th century, an arrangement had developed to govern corporations' duties toward the community. Accordingly, corporations were required to embrace "a degree of minimal protection for individuals dealing within the system of a concentrate." If in The Modern Corporation and Private Property Berle envisioned corporations acting as trustees for the community, by 1952 he viewed the corporation as "an arm of the state, held to certain of the limitations imposed on the state itself by the Bill of Rights requiring the concentrate to respect certain individual rights and to assure a measure of equal protection of the laws within the scope of its power" (643). Collective institutions were to "be so handled that they [could] and [did] acceptably perform their functions of supply and growth." But within these collectives, "and as an offset to their necessary organization and power, the basic rights of individuals [were to] be as scrupulously protected against them as they were against the erstwhile political state" (661).

Berle of 1952 was not different from Berle of 1932. True, in The Modern Corporation and Private Property, Berle called for a judicial imposition of 
trust on corporations, while in 1952 his argument focused on constitutional constraints. But this was a minor change, and one that reflected not only the rapidly growing intellectual attention to the Fourteenth Amendment and individual rights, but also, and more important, the impossibility of imposing a unified conception of social trusteeship on corporations after the U.S. Supreme Court decision in Erie Railroad Co. v. Tompkins (1938) put an end to the idea of federal common law (Bratton 2001, 768).

Such nuances notwithstanding, Berle, twenty years after the publication of The Modern Corporation and Private Property, remained a pluralist. He believed that corporations were important both for the economy and for American society, and just as he wanted to restrict corporate power to benefit the community, so he thought that corporate power should be limited to protect individual rights. Using cases such as Shelley v. Kraemer (1948) and Marsh v. Alabama (1946) as examples, Berle concluded that "[i]f, for instance, a corporation dealing in goods or services essential to the life of an individual discriminate[d] against a customer on the ground of race or in a matter which invade[d] his Constitutional right of freedom of speech or religion, it would seem that there [was] a violation of the guarantees of the Fourteenth Amendment" $(657-61) .^{26}$

Berle's vision could easily have been embraced by Keynesian economists, Reich, and those concerned about individual liberties, but his focus was different from theirs. Berle's was a collectivist interpretation of decisions that have since become milestones in the modern history of individual rights and liberties. His vision remained grounded in the early-20th-century collectivist understanding of property and in the idea that " $[\mathrm{t}]$ he corporation [had] been the avenue by which change from the private possessory system of the late-18th and the 19th centuries toward the organization system of the 20th century [had] taken place in the United States" (643). As Berle also recognized, the embrace of collectivism gave rise to a dilemma-to the need to draw a balance between the rights of corporate members to promote their interests through collective action and the rights of individuals outside the corporation. He wanted to keep intellectual discussions focused on this pluralist dilemma, and he saw decisions like Shelley $v$. Kraemer and Marsh v. Alabama as offering ways out of it. ${ }^{27}$

26. For earlier arguments in favor of imposing constitutional constraints on corporations, see Justice John M. Harlan's dissenting opinion in the Civil Rights Cases. As William Forbath details, such an argument also played a role in the creation of the Fair Employment Practices Commission during World War II and (failed) attempts in the 1940s to make it permanent (2001, 211-15). For a more recent articulation of this argument see Miller 1976. See also Phillips 1989.

27. As Berle put it:

[t]he emergence of the concept of protection of individuals, be they suppliers or customers, along with the emerging system of rights of labor and workmen, means in substance a system of protection for the individuals constituting all of the groups with 
Calling attention to the pluralist dilemma and shifting scholarly focus from administrative processes to constitutional limitations was Berle's legal pluralist response to the changing trends in American thought. It focused on the relationship of the corporation with individuals who came in contact with it. Yet, as Berle well recognized, to accommodate the individualist turn in legal scholarship, more urgent was the need to articulate a theory of managerial fiduciary duties that would be predicated upon viewing the corporation as an entity rather than as aggregation of property owners. As the following section explains, at stake was the emerging image of the shareholderowned corporation, an image that was foreign to Berle's thought and to legal pluralism more broadly.

\section{The (Legal) Pluralist Alternative II: For Whom are Corporate Managers Trustees?}

The Modern Corporation and Private Property concluded that corporate power was to be exercised in trust for the community; accordingly, corporate managers were fiduciaries for the community at large. But, as students of managerial fiduciary duties know, the norm underlying the doctrine of fiduciary duties (at least since the famous 1919 case, Dodge v. Ford) has rested on the assumption that "[a] business corporation is organized and carried on primarily for the profit of the stockholder" (Dodge 684). Berle himself seemed to have endorsed this position in a famous debate with E. Merrick Dodd of Harvard Law School, a debate that took place "[d]uring the penultimate stage of The Modern Corporation's creation" (Schwarz 1987, 64). While Dodd asserted that corporate managers were "fiduciaries for the corporation and not merely for its individual members, that they [were] ... trustees for an institution rather than attorneys for the stockholders" (1932, 1160; Weiner 1969; Sommer 1991), Berle proclaimed that corporate powers were held in trust for the benefit of shareholders $(1931,1049)$. As Berle pointedly put it, the legal system would "best be protecting the interests" it knew-that is property interests- "being no less swift to provide for the new interests as they successively appear[ed]" $(1932,1367){ }^{28}$

which a great corporation comes into contact. And here perhaps is the deep cleft between the systems now competing for dominance in the modern, industrialized world.

... The legal structure in our system subjects the dominant economic organization and the holder of the power created by it to limitations for the purpose of protecting individuals in their essential freedom. It subjects them to a measure of planning for the protection of the community as a whole. $(1952,660)$

28. Already in The Modern Corporation and Private Property certain paragraphs seemed to advocate fiduciary duties toward shareholders. As I argued elsewhere, it seems that Means was more sympathetic to the interests of the community at large than Berle. The seeming inconsistencies in the book might thus reflect the different assumptions of its two authors (Tsuk 2003, 1890). For Means's perspective, see Means 1935, 66. 
However, in 1954, Berle proclaimed that Dodd had won the debate; he concluded that "modern directors [were] not limited to running business enterprise for maximum profit, but [were] in fact and recognized in law as administrators of a community system" (Berle 1960, xii; 1954, 169). Surprisingly, there was little evidence to support this argument. As Joseph L. Weiner commented, "[t]he thesis ... that corporate powers [were] held in trust for stockholders could not be established by decisions of the 1920's, but [could] hardly be contradicted [in the 1960s]" $(1969,1466$; Israels 1964). This was also Dodd's assessment in 1942, when he wrote that the New Deal legislation had made his ideal of managers as trustees for workers, consumers, and the community irrelevant for corporate law. According to Dodd, corporate law became fixated on the relationship between managers and shareholders $(546-47) .^{29}$

One might want to attribute Berle's concession to his ambivalence on the subject. Another reason might have been the famous case, A. P. Smith Manufacturing Company v. Barlow (1953), in which the Supreme Court of New Jersey upheld a New Jersey statute authorizing corporate charitable contributions. An appeal to the U.S. Supreme Court, in which Berle represented the company's shareholders, was dismissed for the want of a substantial federal question. It was then that Berle, maybe even bitterly, conceded to Dodd.

Yet there was more to Berle's debate with Dodd, his role in Barlow v. A. P. Smith Manufacturing Company (1953), and his concession than the discussion above suggests. Berle's positions on the question of fiduciary duties in the 1930s and in the 1950s were informed by his legal pluralist vision of the state and corporations. As I argue below, the differences in his approach had to do with the changing tides of American legal thoughtwith the shift from pluralism to individualism.

First, it is important to remember that Berle wrote the article that instigated his debate with Dodd "in reaction to the apparently unlimited powers conferred on corporate management by recently enacted corporation statutes and charter provisions" (Weiner 1969,1458). His role in Barlow v. A. P. Smith Manufacturing Company was motivated by similar concerns about statutes authorizing charitable contributions by corporations. ${ }^{30}$

29. Dodd noted that in the decade that had passed since his debate with Berle, the nation turned not to "industrial government, as represented by corporate managers, but to political government" to resolve economic tensions. Business obligations toward labor were accordingly "accomplished by means other than treating business managers as in some measure fiduciaries for their employees." Such alternative means included statutory rights, unionization, and collective bargaining. In a similar manner, Dodd described the idea that managers were trustees for consumers or the community as "a misnomer" $(1942,546-47)$.

30. Indeed, charitable contributions were an exception in most state statutes. As one commentator in the 1950s noted, with the exception of provisions in statures authorizing corporate gifts to charity, the theory of corporate social responsibility, while it "[had] been much discussed by philosophers of corporation law, ... [had] almost no reflection in the actual 
In the mid-1930s, in light of statutes granting broad discretion to corporate management, Berle, the legal pluralist, feared that Dodd's position (extending fiduciary duties to all corporate claimants) would encourage a struggle of interest groups and turn the corporation into a battleground, with each group - the laborers, the security holders, the consumers-seeking "to assert ... [its] ... private claims ... by force or threat-to take what each [could] get, just as corporate management" did (Schwarz 1987, 65).

If we were to extend managerial fiduciary duties to other groups, Berle concluded in the 1930s, it would be "an invitation not to law and orderly government, but to a process of economic civil war" (Schwarz 1987, 65). Instead, Berle wanted the courts to protect the rights of shareholders as property owners because he saw shareholders' interests as an approximation of community interests (Tsuk 2003, 1891-94). Of the plurality of interests involved in corporations, shareholders' interests were the connecting tissue between corporations and the community-a means to a socially desirable outcome. To use Mary Parker Follett's terminology, shareholders' interests were the integrative force, the force that would prevent society from splitting into autonomous centers of power.

Berle believed that by protecting the property rights of shareholders, the courts would be able to tame corporate power in ways that contemporaneous legislation failed to do (Warren 1964, 1383). As Berle explained in a 1962 exchange with Henry G. Manne, he did not endorse his position in the debate with Dodd because he believed that shareholders had the only claim on corporate profits, but rather because

[he] was afraid of corporate managements as social statesmen, or possibly as controlling fund-donors for universities and other philanthropies, not because [he] objected to the job being done, but because [he] thought corporate managements were not especially qualified to do it. In doing it they might revert to their classic profit-making function, and in that case would do the job badly—or worse (443).

In other words, Berle's view of shareholders' interests did not focus on questions of profits, efficiency, or capital markets. He did not seek to evaluate whether or not shareholders' profits were maximized. Rather, Berle's understanding of shareholders' interests was mediated by his conceptualization of property rights as delegating sovereign power to the owners. Berle believed that property rules could therefore define the boundaries of freedom (of the owners, of the controlling group, and of the corporation as an entity).

statutes" (Katz 1958, 180-81). Having witnessed state legislators eroding all constraints on corporate power, it seems that Berle took the appeal in Barlow v. A. P. Smith Manufacturing Company because he wanted a declaration from the courts about corporate power with respect to the only issue where it still mattered - charitable contributions. 
In this respect, it is also important to recall that Berle's conception of fiduciary duties was inspired by his desire to create a shareholder class- to encourage "the middle and working classes ... [to] ... entrust their savings, through organizations such as savings banks or pension funds, to the securityrather than the risk - of the stock exchanges." Berle wanted to be the "Marx of the shareholder class" (B. Berle and Jacobs 1973, 26; Schwarz 1987, 65). ${ }^{31}$ This was his alternative to the Progressive notion of shareholder democracy"the idea of restoring active control to shareholders," which "held far wider appeal at the time" (Hessen 1983, 278-79). ${ }^{32}$

The Modern Corporation and Private Property did not endorse shareholder democracy because Berle and Means viewed the idea as implausible in large business corporations with their dispersed (passive) ownership (Schwarz 1987, 62-68). Berle wanted to make managers trustees for the shareholders because he saw shareholders as representing the community. However, by the 1950s, when Berle conceded to Dodd, both the idea that shareholders' interests would become a proxy for community welfare and the ideal of a shareholder class had dissipated. First, as a 1958 study (by J. A. Livingston) of the role of shareholders - as affected by "SEC regulation, extensive disclosure requirements, elaborate proxy machinery, Stock Exchange selfdiscipline, corporate Good Citizenship, People's Capitalism and Corporate Democracy"-demonstrated, shareholders remained passive (or impotent) (Manning 1958, 1485). More important, shareholders never became a class, and in the postwar years they were viewed as merely another interest group. For one thing, those who seemed to embrace Berle's position in his debate with Dodd (like Eugene Rostow) described shareholders not as a class with shared social and political goals, but as individuals sharing an economic (investment) interest (Rostow 1960, 53-54).

In this atmosphere Berle renounced his early position. It was not his loss of the appeal in Barlow v. A. P. Smith Manufacturing Company, but rather the changing tides of corporate law (and legal thought more broadly) that triggered his concession to Dodd. Berle seemed particularly troubled by a new image of the corporation, which economists and legal scholars began to articulate in the postwar years, and which threatened to eclipse his legal pluralist vision. Reflecting the individualist turn in scholarly circles, this new vision was presumably meant to emphasize the role of the individual investor in the corporation, but in contrast to Berle's belief that shareholders' interests could serve as a means of constraining corporate power, this new vision sought to empower shareholders to pursue their own interests-specifically profit.

Given his social and political sensibilities, Berle feared that this new vision of the corporation would be detrimental to the American economy, a

31. On the contentious relationship between pluralism and class, see Tsuk 2003.

32. Indeed, as Progressives explored union democracy, they also examined the possibility of shareholder democracy. Both visions rested on the assumption that groups had to be controlled by their members. 
fear that recent corporate scandals might have proven justifiable. With this in mind, Berle not only embraced a more favorable view of corporate management (1960, xiii), but also conceded to Dodd. In an attempt to save the message of The Modern Corporation and Private Property, and the legal pluralist vision more broadly, Berle, again, made managers trustees for the community. Emphasizing managers' duties toward the community at large was Berle's response to the rising tides of individualism. Yet, as the following part concludes, neither Berle nor Means could save modern corporate theory from the individualist turn. Sadly, they could not even save their own book from being functionally rewritten or misinterpreted.

\section{PART III: 1983-THE MODERN CORPORATION AND PRIVATE PROPERTY TRANSFORMED}

\section{The New Economic Theory of the Firm}

One of the most striking characteristics of The Modern Corporation and Private Property was the absence of theoretical economics. While Means was an economist, his chief contribution was his statistical studies. Beyond these studies, "[e]xcept for an occasional citation to Adam Smith and one to Thorstein Veblen's Absentee Ownership, there was no discussion of economic literature" in the book. As the first part of this essay demonstrated, for the most part, The Modern Corporation and Private Property was meant to bring the political theory of pluralism to bear upon legal doctrine. Indeed, "most economists ignored Berle and Means." For one thing, Ronald Coase, whose pathbreaking article, "The Nature of the Firm," was published only five years after the publication of The Modern Corporation and Private Property, "never cited Berle's and Means's work and virtually ignored the 'legal' literature on the structure of the business firm" (Hovenkamp 1988, 1684).

The separation between law and economics, as it was reflected in The Modern Corporation and Private Property and in its reception among economists, was not surprising. Like other strands of Progressive legal thought, Berle and Means's legal pluralism was informed by a marginalist economic theory, which justified "widespread, state-enforced wealth distribution and intervention in the market." In turn, the mainstream of economic thought beginning in the 1910 s was "increasingly skeptical, indifferent and eventually hostile toward concepts of social value-or to any concept of value that could not be defined strictly in terms of individual preference," and thus "increasingly strict and pessimistic about the science of measuring welfare." The result was a sharp separation of law and economics in American thought from the 1930s through the 1960s. Mainstream economists developed "the neoclassical theory of competition," while legal scholars 
continued to rely on regulatory agencies to allocate resources (Hovenkamp 2000, 810-11, 836).

The shift in legal and political theory-from collective institutions to individuals as the foundation for the modern state-coupled with the growing faith in the power of economic and political markets to produce the common good, opened a door for the reintroduction of economics into law. As (progressive) legal scholars' concerns shifted from wealth and class toward a wide range of indicia of lack of privilege, including "race, extremist political or social views, indigent criminal defendants, alienage, and eventually gender, affectional preferences and disabilities," the cohesion of their thought gradually disintegrated. The only common thread seemed to be individual preferences (Hovenkamp 2000, 860-61). In such an atmosphere, the new economic theory of the firm emerged.

Prior to the 1970s, neoclassical economics focused its theorizing efforts on markets and declined to theorize about the corporation's internal structure. Accordingly, the firm was a "black box"; it followed "profit considerations exclusively" as "an entity in rational patterns no different from those of human actors," and market forces were deemed to control managerial power (Bratton 1989a, 1495-96). The relationship between the actors within the box remained the terrain of legal doctrine, as it was developed in the courts, and of "organization theory specialists" (Williamson 1983, 365).

Then, as the gap between law and economics was being bridged, neoclassical economists (many of whom were influenced by Ronald Coase's analytical juxtaposition of markets and organizations) turned to corporate structure (and legal doctrine) (Williamson 1983, 365; Bratton 1989a, 1498). Their new economic theory of the firm offered a picture of the corporation that fit the market-centered economic policies of the postwar years and their culmination in the $1980 \mathrm{~s}^{33}$ Rather than putting management hierarchies and the need to constrain corporate power at the center of the corporate paradigm, the new economic theory of the firm found a way around hierarchy and regulation by drawing on microeconomics to describe corporate entities as nexuses of private, contractual relationships and to paint a new picture of the firm and economic markets in which "hierarchy [was] irrelevant." The corporation was merely a collection of "disaggregated but interrelated transactions" among individuals (or between them and the fictive entity, "as a matter of convenience") (Bratton 1989b, 416-20).

The new theory of the firm supported a shift of focus in scholarly debates-from questions of power, influence, sanctions and legitimacy to

33. As commentators have demonstrated, despite "record inflation[,] ... the worst recession since the 1930s," and the flourishing of proposals for different economic planning at the state and federal level, by the early 1980 s, the U.S. economic policy heavily relied on market allocation of resources. The concerted efforts of the new, sufficiently unified class of business leaders and large investors helped reduce to a minimum constraints on capital, either by organized labor or the state (Akard 1992, 600-608). 
issues of cost reduction and profit maximization (Bratton 1989a, 1498). Investors, managers, workers, and all other corporate constituencies were presumed to be self-interested wealth-maximizers operating in formally free markets. Concerns about managerial expertise were translated into questions about economic efficiency, and managers described corporate activities in the social sphere as "the pursuit of profit." Public problems such as discrimination and growing disparities of wealth were depicted as providing industries with "opportunities for growth and profit" (Blumberg 1972, 5; Zeitlin 1974, 1094-97).

Those who embraced the new economic theory of the firm were quick to denounce the concerns about corporate power as articulated in The Modern Corporation and Private Property. As early as 1962, in a review essay of The Modern Corporation and Private Property, Henry Manne, for example, announced that Berle and Means's predictions about the detrimental economic effects of the concentration of corporate power, as well as calls for the reform of corporate law that drew on Berle and Means's analysis, were wrongheaded. According to Manne, those who expressed concerns about the real impact of shareholders' votes neglected to recognize the relationship between share voting and share transferability (407-13). In turn, those who advocated business statesmanship did not realize that statesmanship mattered only when "the degree of monopoly in the economy" was high. As Manne put $i t$, when the economy functioned in a competitive way, non-profit-maximizing activities would take place only if "the shareholders [had] agreed to operate something other than a purely business association" (413-18). Finally, those who called for the application of constitutional standards to corporations failed to understand that when "all important activities of individuals or private associations [had to] meet some nebulous standard of 'social purpose,' freedom as we [had] known and yearned for it [would] have disappeared" (423-30).

What, then, was left of the message of The Modern Corporation and Private Property? As Manne saw it, the only theme of the book that was worth examining was the separation of ownership from control in the modern corporation. Manne described this theme as the "central theme" of the book, and "one that [had] found most general acceptance" (399-400). Then, he called on scholars to recognize the concerns about efficiency that the separation of ownership from control triggered and to study how capital markets could eliminate such concerns (430-32).

In other words, even with respect to the narrow problem of the separation of ownership from control, Manne rejected Berle and Means's conclusions. While Berle and Means tied the separation of ownership from control to the corporation's ability to amass power, Manne dismissed any concerns about corporate power. While Berle and Means emphasized that because of the separation of ownership from control, "competition could no longer be trusted to guarantee efficient corporate behavior" (Hovenkamp 
1988, 1684), Manne suggested that market competition was a means of bridging the gap between ownership and control.

This was also the message of a series of articles evaluating the importance of The Modern Corporation and Private Property that were published in 1983 in the Joumal of Law and Economics. The authors of these articles, almost exclusively members of the burgeoning law and economics movement, implicitly engaged Manne's call. As the following sections elaborate, together they so transformed the message of The Modern Corporation and Private Property that even its authors could not recognize the book.

\section{The (Profitable) Separation of Ownership from Control}

The papers published in volume 26 of the Journal of Law and Economics were produced for a conference, Corporations and Private Property, held by the Hoover Institution in celebration of the fiftieth anniversary of The Modern Corporation and Private Property. Being a celebration, it began with commemorative introductory remarks (by Thomas Gale Moore), which suggested that the book tremendously influenced different reform ideas, including Ralph Nader's proposal for federal incorporation laws, Tom Hayden's proposal for corporate democracy, and even the German policy of codetermination $(1983,236)$.

However inaccurate the suggestion that the book influenced all these movements was, the tribute to the book's social and political legacy ended with these remarks. The following papers transformed The Modern Corporation and Private Property into a book concerned not with corporate power, as it was, but with the separation of ownership from control. For example, George J. Stigler and Claire Friedland asserted that the theme of The Modern Corporation and Private Property was the emergence of "a new era of economic organization because of the separation of ownership and control." Noting Berle and Means's exploration of the "growing concentration of economic power in large corporations," Stigler and Friedland dismissed it as "no necessary part of the separation of ownership and control," and indeed as an exploration serving merely "to emphasize the social urgency of the problem of controlling the large corporation" (238-39). ${ }^{34}$ Leonard Weiss further asserted that aggregate concentration fell sharply after 1929, making Berle and Means's concerns about corporate power irrelevant (448). And Harold Demsetz simply began by noting that "[t]he separation of ownership from

34. In a symposium held at the University of California in Los Angeles also in 1983, George A. Stigler was quoted to have said the following (provoking laughter from the audience): "[Berle and Means] planted once and for all the idea that the two hundred largest corporations in America are bigger than the other biggest corporations [laughter] and that the ownership and control of the modern corporation are wholly separated from one another" (Kitch 1983, 174). 
control in the modern corporation, an issue brought to the fore so effectively by Berle and Means fifty years ago, retains a central position in recent writings about the economic theory of the firm" (375).

Having shifted attention from corporate power to the separation of ownership from control, the conference participants went on to demonstrate that the problem, truly, was not a problem. First, they proclaimed that it could not be a problem as all actors in the corporate endeavor preferred it. For example, Hessen argued that investors were not only "free to choose," but also presented with "rich and diverse choices." They supplied capital "because they [had] sufficient savings they [were] willing to entrust to the managerial skills of others, in return for a share in the resulting profits" (28589). Easterbrook and Fischel asserted that investors knew how to protect their interests contractually, and Demsetz concluded that shareholders chose to be passive investors because it allowed them to maximize their profits. If needed, they could and would become active-through takeovers, proxy fights, and purchase of control (387-90).

Furthermore, according to the conference participants, not only was the separation of ownership from control the preferred choice of investors, but it also proved to be an efficient choice. For one thing, Stigler and Friedland announced that their "statistical analyses, using only data and methods familiar to economists of the [1930s], yield[ed] no clear evidence that the management-dominated corporations differed much from owner-dominated companies ... in the utilization of assets to produce profits" (259). Demsetz declared that, in fact, there was no real distinction between investors' and managements' interests. Rather, both groups shared a "considerable interest in profit-maximizing behavior" (390). Finally, Eugene Fama and Michael Jensen asserted that organizational forms survived because of the "comparative advantages of characteristics of residual claims in controlling the agency problems" (1983a, 345), and that "the contract structure" of the modern corporation, by separating "the ratification and monitoring of decisions from initiation and implementation of decisions," effectively controlled "the agency problems caused by separation of decision and risk-bearing functions" (1983b, 302).

Of course, once the separation of ownership from control was proven not to be a problem, Berle and Means's proposed legal regime could easily be dismissed. In this vein, the conference participants wholeheartedly rejected the idea that corporations were trustees for the community. As Hessen pointedly explained, investors' (free) decision

to entrust their wealth to professional managers [did] not make them, as Berle and Means claim[ed], inactive and irresponsible. Their rights should be protected, not eroded, as Berle and Means propose[d] when they [said] that the shareholders "by surrendering control and responsibility ... have released the community from the obligation to 
protect them to the full extent implied in the doctrine of strict property rights." (289)

But even more modest (progressive) suggestions of imposing a regime of fiduciary duties toward shareholders or strengthening shareholders voting power were rejected as interferences with the voluntary nature of participation in the firm's activities. For example, Easterbrook and Fischel criticized all constraints on shareholders' voting, specifically those imposed by the securities acts of 1933 and 1934, as unnecessary and leading to ineffcient results. "These rules," they wrote, "displace[d] voluntary arrangements as codified in the common law rules and thus impose[d] costs that probably outweigh[ed] any benefits" (427). In turn, Demsetz undermined all forms of mandatory fiduciary duties by explaining that "[i]n a world in which selfinterest play[ed] a significant role in economic behavior, it [was] foolish to believe that owners of valuable resources systematically relinquish[ed] control to managers who [were] not guided to serve their interests." The legal system could thus trust the self-interested shareholders to discipline management (if necessary) through market power (390; Ricardo-Campbell 1983). The firm's contracts were supposed ("priced") to take management self-interest, including excessive self-dealing, into account, and the legal community could assume that if the shareholders did not accept certain behavior, it would become too costly and disappear. Not even a supplemental legal regime of fiduciary duties was necessary (Bratton 1989a, 1499).

Indeed, while calling attention away from corporate power and toward Berle and Means's exegesis of the separation of ownership from control might seem a mere shift in emphasis, the conference participants well recognized that it was also a means to an end. The phenomenon of the separation of ownership from control could be employed to legitimate different legal regimes. Berle and Means used it to support their argument about corporate power and corporate duties. In a similar manner, as Demsetz elaborated, many social critics, from Veblen to Galbraith, used it to justify giving expert management, rather than individual capitalists, the power efficiently to run the corporation (376). The conference participants, and advocates of the new economic theory of the firm more broadly, called for a different usage-one that focused on capital markets and the (presumably) common search for profit. In their hands, the endurance and seeming effectiveness of the separation of ownership from control helped legitimate the idea that market competition and the search for profit were the only means of regulating corporate power. As such, the separation of ownership from control became a solution rather than a problem-it was the ultimate way to allow self-interested investors to profit.

In short, reading The Modern Corporation and Private Property as a book about the separation of ownership from control helped minimize the concerns that Berle and Means expressed about corporate power and negate 
Berle and Means's regulatory solution, which viewed corporations as public trustees. At the same time it also helped legitimate a different solution-a market-oriented solution. Informed by the individualist turn of the postwar years, the law and economics scholars of the 1970s and 1980s turned the corporation-a social, economic, and political organization-into a contractual arrangement, a tool of making profits for investors. ${ }^{35}$ Even at the turn of the 21 st century, after the market has proven to be less efficient in regulating corporate activities, the self-interested search for profit has remained the theme underlying corporate law.

Gone was Berle and Means's concern with corporate power, gone was their concern with managerial fiduciary duties. All that was left was a book about efficiency and profit. All that was left was a book about which Gardiner Means, writing in response to one of the papers in the symposium, said the following: "I find great difficulty in recognizing the book described by Dr. Hessen as the book we wrote fifty years ago" (1983b, 297).

\section{Berle and Means's Lost Battle}

Proponents of the new economic theory of the firm were adamant about rejecting Berle and Means's emphasis on power and the need to constrain corporate power (either through a judicial-based trust doctrine or federal regulation). Both Berle and Means's concern and their remedy undermined the individualist, profit-oriented, vision of the corporation. Writing, ahistorically, more than five decades after the New Deal had transformed the corporation, they could not appreciate Berle and Means's concerns. As Berle sharply put it in his response to Manne in 1962:

Professor Manne and his contemporaries did not live through World War I and the decade of the twenties, and the crash of 1929 , culminating in the breakdown of the American economic system in 1933. They have not experienced a corporate and financial world without the safeguards of the Securities and Exchange Commission, without systemization and enforced publicity of corporate accounting, without (more or less) consistent application of antitrust laws, without discouragement of financial pyramiding, and which tolerated conflicts of interest to a degree unthinkable now. They have not experienced a

35. As Fama and Jensen put it: "An organization is the nexus of contracts, written and unwritten among owners of factors of production and customers. These contracts or internal 'rules of the game' specify the rights of each agent in the organization, performance criteria on which agents are evaluated, and the payoff functions they face. The contract structure combines with available production technologies and external legal constraints to determine the cost function for delivering an output with a particular form of organization. The form of organization that delivers the output demanded by customers at the lowest price, while covering costs, survives" (1983b, 302). 
banking, credit, and currency system unguided by the Federal Reserve Board. Least of all have they lived in a political-economic world in which great corporations were not consistently held by active public opinion to public responsibility. (433)

It did not surprise Berle that the new generation of corporate law scholars, given their lack of firsthand knowledge, turned to the classical, "nineteenth century economic postulate that the free market under competitive conditions [was] the best" (435). But, Berle emphasized, this assumption could not be sustained given the economic changes that took place in the 20th century, specifically the aggregation of corporate power. Indeed, according to Berle, because they did not understand the importance of power and hierarchy to the corporate structure, advocates of the new theory of the firm could describe the shareholders' vote, which Berle viewed as merely a "ritual," as meaningful. Because they endorsed the classical (or neoclassical) economic vision of the rational, profit-maximizing actor, they could not realize that business statesmanship was real and not always "dictated by market conditions." Finally, because they refused to recognize the realities of corporate power, they misconceived the nature of corporate entities. "In fact," Berle stressed, "a large corporation is a variety of non-statist political institution" (442-45).

For Berle, writing three decades after the publication of The Modern Corporation and Private Property, the problem remained corporate power, and this question of power remained entangled with the question of passive property. Neither, however, could be answered by reference to 19th-century conceptions of property. As Berle reiterated, what the separation of ownership and control indicated, in 1932 and in 1962, was the need for new social and political concepts of property and corporations.

Berle's 1962 solution to the problem of power focused on the nature of shareholding. Still, like his earlier solutions, Berle's 1962 discussion of shareholding focused on the social and political nature of ownership, specifically corporate ownership. Just as Reich sought to give individuals entitlements to government benefits, Berle grounded the ownership of shares in social reasons, emphasizing the "value attached to individual life, individual development, individual solution of personal problems, individual choice of consumption and activity." Shareholding allowed for an equitable distribution of these goods; and shares were, accordingly, not an entitlement but a mechanism of wealth distribution $(1965,17)$. As Berle elaborated:

Passive property ... loses its "capital" function and becomes increasingly an exclusive means for distributing liquid wealth, and a channel for distributing income whose accumulation for capital purposes is not required....Beyond that. . .the right to choose consumption-to spend 
if and as you please-will be guarded as a defense of the individual's right to order his own life. (20)

In 1967, in the preface to the revised edition of The Modern Corporation and Private Property, Berle reiterated his conclusions. He described the ongoing current toward collective (or corporate) capitalism; he redrew the distinction between consumption property (which allowed individuals to express their personality) and productive property (which was subject to constitutional limitations); finally, he emphasized the role of passive property in distributing wealth. "There is," Berle concluded, "increasing recognition of the fact that collective operations, and those predominantly conducted by large corporations, are like operations carried on by the state itself." Accordingly, corporations were "political constructs": "Their perpetual life, their capacity to accumulate tens of billions of assets, and to draw profit from their production and their sales, has made them part of the service of supply of the United States. Informally they are an adjunct of the state itself" (1967b, xxvi-xxvii).

Means shared Berle's conclusions. In 1967, in his preface to the revised edition, Means noted that the corporate revolution created "centers of economic power on a scale never previously known." In turn, the separation of ownership and control "has released management from the overriding requirement that it serve stockholders." In short, Means continued to stress that The Modern Corporation and Private Property illustrated that the growth of corporate power demanded new concepts to replace the old concepts of "wealth, enterprise, initiative, the profit motive, and competition" (xxxiv-xxxv).

In 1983, Means reiterated his call. Writing in response to one of the papers in the conference Corporations and Private Property, Means complained that by limiting their perception of the book to what it said about the separation of ownership from control, the participants failed to realize that the main thrust of the book concerned "the effect of the modern corporation on the working of the economy as a whole" (1983b, 297-98). Specifically, they failed to recognize the crucial question of the book: "How can public policies that can work reasonably well when most enterprises are small, closely held, and highly competitive, be expected to work when an important part of production is carried on by giant enterprises with dispersed ownership and fewer competitors?" (300). According to Means, the most important contribution of the book was the chapter on the concentration of economic power (1983a, 469).

In short, according to Berle and Means, not the microeconomic question of the separation of ownership from control, but the macroeconomic problem of power underlay the concerns that they expressed in The Modem Corporation and Private Property. It was the problem of corporate power that called for the creation of new concepts. It was the problem of 
power that advocates of the economic theory of the firm were trying to eradicate, but it was that problem, too, that made The Modern Corporation and Private Property an enduring book.

Yet, enduring as the book's legacy was, it could not stop the neoclassical vision from having the upper hand or from rewriting the book's message. In 1962, Berle labeled Manne's approach "a last ditch stand of the nineteenth-century school" (436). In 1967, both Berle and Means seemed optimistic about the possibility of developing new concepts. But in 1983, twelve years after Berle's death, Means was fighting a lost battle. Concluding his article for the conference, Corporations and Private Property, he wrote:

I must reiterate our conclusions that: "Competition has changed in character and the principles applicable to present conditions are radically different from those which apply when the dominant competing units are smaller and more numerous"; and that "New concepts must be forged and a new picture of economic relationship created." (1983a, 485)

For Means these words continued to ring urgently, but in 1983 the new economic theory of the firm, which has shifted the focus of corporate law and theory from questions of social and economic power to the maximization of value for investors-from new (collectivist) concepts to old (individualist) ones- has so transformed Berle and Means's words that the true (and lasting) meaning of their book seems to have disappeared from our collective memory.

\section{EPILOGUE}

In 1959, Robert Dahl proclaimed that the early discourse of pluralism, which provided political scientists and lawyers alike with tools to examine the business corporation as a political order, was lost. Specifically, Dahl noted that while political scientists remained interested in "the relatively well established field of government regulation in the broad sense," they had left the study of the internal order of the corporation to economists. According to Dahl, in so doing, political theorists helped remove "questions of power, influence, sanctions, [and] legitimacy"-that is, questions of government and political order-from the study of the firm. Dahl wanted his audience to rerecognize the importance of these questions to the study of corporations. "A business firm," he stressed, "like a trade union, religious organization, or state, [had] a political order" (3-6).

This was indeed the assumption underlying The Modern Corporation and Private Property. Berle and Means described corporations as real entities and called attention to the fact that corporations exercised power, which 
resembled the power of the sovereign state, and which could not be absolutely curbed. "To us," Berle declared, "there is much to indicate that the process will go a great deal further than it has now gone" (p. viii). Given the reality of corporate power, Berle and Means urged their audience to study the modern corporation "as a human institution" ( $p$. viii). Then, Berle and Means sought, even if unsuccessfully, to articulate legal rules that would tame or channel corporate power to the benefit of society.

In 1959 Dahl was not certain why the early discourse of pluralism, of which he was well aware, was lost. "What seems to have happened," he wrote, "is that the Great Depression and the New Deal turned the attention of political scientists away from explaining behavior to prescribing policy" (17-19).

This essay offered a different narrative. I argued that Berle and Means's pluralist vision influenced much of the New Deal regulatory programs, but in the course of the years that followed, it was eclipsed by a different vision of the state-an individualist one. As I further argued, this individualist vision was reflected in Keynesian economics, in Dahl's neopluralism, in the modern discourse of civil rights, and ultimately in the new economic theory of the firm, which described business corporations as nexuses of contractual relations between individuals, subject only to the regulation of capital markets.

Advocates of the new economic theory of the firm helped obscure the legacy of The Modern Corporation and Private Property, turning it into a book about the separation of ownership from control, not about corporate power. But corporate power is real. Today, corporations capture every aspect of our lives. They contribute to political campaigns, own and control the mass media and rapidly the Internet. Their actions affect families and individuals. Multinational and world trade organizations have changed the nature of economic and political markets, coordinating economic activity across political, cultural, and social boundaries. If the turn of the 20th century witnessed the nationalization of the business corporation with the creation of multistate corporations, the 21 st century confronts the internationalization of the business corporation. Global corporations weaken the capacity of individual countries to control their internal economies, while simultaneously furthering the consolidation of a global society. In this context, the true legacy of The Modern Corporation and Private Property endures. It is left to us, the readers, to preserve its vitality.

\section{REFERENCES}

Akard, Patrick J. 1992. Corporate Mobilization and Political Power: The Transformation of U.S. Economic Policy in the 1970s. American Sociological Review 57:597-615.

Alexander, Gregory S. 1997. Commodity and Propriety: Competing Visions of Property in American Legal Thought, 1776-1970. Chicago: University of Chicago Press. 
Balkin, J. M. 1990. Some Realism about Pluralism: Legal Realist Approaches to the First Amendment. Duke Law Joumal (1990): 375-430.

Barenberg, Mark. 1993. The Political Economy of the Wagner Act: Power, Symbol, and Workplace Cooperation. Harvard Law Review 106:1379-1496.

Bell, Daniel. 1960. The End of Ideology: On the Exhaustion of Political Ideas in the Fifties. Glencoe, Ill.: Free Press.

Bentley, Arthur F. 1908. The Process of Government: A Study of Social Pressures. Chicago: University of Chicago Press.

Berle, Adolf A., Jr. 1928. Studies in the Law of Corporation Finance. Chicago: Callaghan and Company.

1931. Corporate Powers as Powers in Trust. Harvard Law Review 44:1049-74.

. 1932. For Whom Corporate Managers Are Trustees: A Note. Harvard Law Review 45:1365-72.

1952. The Developing Law of Corporate Concentration. University of Chicago Law Review 19:639-61.

1954. The 20th Century Capitalist Revolution. New York: Harcourt, Brace and Company.

- 1960. Foreword. In Mason 1960, ix-xv.

- 1962. Modern Functions of the Corporate System. Columbia Law Review 62:433-49.

- 1965. Property, Production, and Revolution. Columbia Law Review 65:1-20.

- 1967a. Power. New York: Harcourt, Brace and World.

- 1967b. Property, Production and Revolution: A Preface to the Revised Edition. In Berle and Means 1968, vii-xxvii.

Berle, Adolf A., Jr., and Gardiner C. Means. 1930. Corporations and the Public Investor. American Economic Review 20:54-71.

1932. The Modern Corporation and Private Property. New York: Macmillan. . 1968. The Modern Corporation and Private Property. Rev. edition. New York: Harcourt, Brace and World.

Berle, Beatrice Bishop, and Travis Beal Jacobs, eds. 1973. Navigating the Rapids, 19181971: From the Papers of Adolf A. Berle. New York: Harcourt Brace Jovanovich.

Blumberg, Phillip I. 1972. Corporate Responsibility in a Changing Society: Essays on Corporate Social Responsibility. Boston: Boston University School of Law.

Bowman, Scott R. 1996. The Modern Corporation and American Political Thought: Law, Power, and Ideology. University Park: Pennsylvania State University Press.

Bratton, William W., Jr. 1989a. The New Economic Theory of the Firm: Critical Perspectives from History. Stanford Law Review 41:1471-1527.

— 1989b. The "Nexus of Contracts" Corporation: A Critical Appraisal. Comell Law Review 74:407-65.

- 2001. Berle and Means Reconsidered at the Century's Turn, Joumal of Corporation Law 26:737-70.

Brinkley, Alan. 1989. The New Deal and the Idea of the State. In Fraser and Gerstle 1989, $85-121$.

- 1995. The End of Reform: New Deal Liberalism in Recession and War. New York: Alfred A. Knopf.

Brudney, Victor. 1997. Contract and Fiduciary Duty in Corporate Law. Boston College Law Review 38:595-665.

Butler, Henry N. 1989. The Contractual Theory of the Corporation. George Mason University Law Review 11:99-123.

Butler, Henry N., and Harry E. Ribstein. 1990. Opting Out of Fiduciary Duties: Response to the Anti-contractarians. Washington Law Review 65:1-72.

Carver, Thomas N. 1925. The Present Economic Revolution in the United States. Boston: Little, Brown and Company. 
Chayes, Abram. 1960. The Modern Corporation and the Rule of Law. In Mason 1960, $25-45$.

Coase, Ronald H. 1937. The Nature of the Firm. Economica 4:386-405.

Coffee, John C., Jr. 1989. The Mandatory/Enabling Balance in Corporate Law: An Essay on the Judicial Role. Columbia Law Review 89:1618-92.

Cohen, Morris R. 1927. Property and Sovereignty. Comell Law Quarterly 13:8-30.

Columbia Law Review. 1989. Symposium: Contractual Freedom in Corporate Law. Columbia Law Review 89:1395-1775.

Dahl, Robert A. 1956. A Preface to Democratic Theory. Chicago: University of Chicago Press. . 1959. Business and Politics: A Critical Appraisal of Political Science. In Robert A. Dahl, Mason Haire, and Paul F. Lazarsfeld eds. Social Science Research on Business: Product and Potential. New York: Columbia University Press.

1967. Pluralist Democracy in the United States: Conflict and Consent. Chicago: Rand McNally.

Demsetz, Harold. 1983. The Structure of Ownership and the Theory of the Firm. Joumal of Law and Economics 26:375-90.

Dewey, John. 1927. The Public and Its Problems. New York: Henry Holt and Company.

Dodd, E. Merrick. 1932. For Whom Are Corporate Managers Trustees? Harvard Law Review 45:1145-63.

-. 1942. Book Review: Bureaucracy and Trusteeship in Large Corporations by Marshall E. Dimock. University of Chicago Law Review 9:538-49.

Dudziak, Mary L. 2001. Cold War Civil Rights: Race and the Image of American Democracy. Princeton, N.J.: Princeton University Press.

Easterbrook, Frank H., and Daniel R. Fischel. 1983. Voting in Corporate Law. Journal of Law and Economics 26:395-427.

- 1991. The Economic Structure of Corporate Law. Cambridge, Mass.: Harvard University Press.

Eisenberg, Avigail I. 1995. Reconstructing Political Pluralism. Albany: State University of New York Press.

Ernst, Daniel R. 1993. Common Laborers? Industrial Pluralists, Legal Realists, and the Law of Industrial Disputes, 1915-1943. Law and History Review 11:59-100.

Fama, Eugene F., and Michael C. Jensen. 1983a. Agency Problems and Residual Claims. Joumal of Law and Economics 26:327-49.

- 1983b. Separation of Ownership and Control. Journal of Law and Economics 26:301-25.

Follett, Mary Parker. 1918. The New State: Group Organization the Solution of Popular Government. New York: Longmans, Green.

-1924. Creative Experience. New York: Longmans, Green and co. 1925. Power. In Metcalf and Urwick 1942.

Forbath, William E. 2000. Civil Rights and Economic Citizenship: Notes on the Past and Future of the Civil Rights and Labor Movements. University of Pennsylvania Journal of Labor and Employment Law 2:697-718.

- 2001. The New Deal Constitution in Exile. Duke Law Journal 51:165-222.

Frank, Jerome. 1933. Book Review: The Modern Corporation and Private Property. Yale Law Journal 42:989-1000.

Fraser, Steve, and Gary Gerstle, eds. 1989. The Rise and Fall of the New Deal Order, 19301980. Princeton, N.J.: Princeton University Press.

Friedlander, Joel Edan. 1996. Corporation and Kulturkampf: Time Culture as Illegal Fiction. Connecticut Law Review 29:31-115.

Friedman, Milton. 1962. Capitalism and Freedom. Chicago: University of Chicago Press. . 1970. The Social Responsibility of Business Is to Increase Its Profits. New York Times, Sept. 13. 
Galbraith, John Kenneth. 1952. American Capitalism: The Concept of Countervailing Power. Boston: Houghton Mifflin.

Genovese, Eugene D. 1997. Secularism in the General Crisis of Capitalism. American Journal of Jurisprudence 42:195-210.

Glasberg, Davita Silfen, and Michael Schwartz. 1983. Ownership and Control of Corporations. Annual Review of Sociology 9:311-32.

Goluboff, Risa L. 2001. The Thirteenth Amendment and the Lost Origins of Civil Rights. Duke Law Joumal 50:1609-85.

Gordon, Jeffrey N. 1989. The Mandatory Structure of Corporate Law. Columbia Law Review 89:1549-99.

Gordon, Robert W. 1995. Legal Realism. In Richard Wightman Fox and James T. Kloppenberg, eds., A Companion to American Thought. Cambridge, Mass.: Blackwell Publishers.

Graham, Pauline, ed. 1995. Mary Parker Follett: Prophet of Management. Boston: Harvard Business School Press.

Hager, Mark M. 1989. Bodies Politic: The Progressive History of Organizational "Real Entity" Theory. University of Pittsburgh Law Review 50:575-654.

Hale, Robert L. 1923. Coercion and Distribution in a Supposedly Non-coercive State. Political Science Quarterly 38:470-94.

Hawley, Ellis W. 1979. The Great War and the Search for Modern Order: A History of the American People and their Institutions, 1917-1933. New York: St. Martin's Press.

Hessen, Robert. 1983. The Modern Corporation and Private Property: A Reappraisal. Journal of Law and Economics 26:273-289.

Hirst, Paul Q. ed. 1989. The Pluralist Theory of the State: Selected Writings of G. D. H. Cole, J. N. Figgis, and H. J. Laski. New York: Routledge.

Horwitz, Morton J. 1992. The Transformation of American Law, 1870-1960: The Crisis of Legal Orthodoxy. New York: Oxford University Press.

Hovenkamp, Herbert. 1988. The Classical Corporation in American Legal Thought. Georgetoun Law Journal 76:1593-1689.

- 2000. Knowledge about Welfare: Legal Realism and the Separation of Law and Economics. Minnesota Law Review 84:805-62.

Isaacs, Nathan. 1933. Book Review: The Modem Corporation and Private Property. Yale Law Joumal 42:463-65.

Israels, Carlos L. 1964. Are Corporate Powers Still Held in Trust? Columbia Law Review 64:1446-57.

Jaffe, Louis L. 1937. Law Making by Private Groups. Harvard Law Review 51:201-53.

Journal of Law and Economics. 1983. Conference: Corporations and Private Property (sponsored by the Hoover Institurion). Journal of Law and Economics 26:235-496.

Kariel, Henry S. 1961. The Decline of American Pluralism. Stanford, Calif.: Stanford University Press.

Katz, Wilber G. 1958. The Philosophy of Midcentury Corporation Statutes. Law and Contemporary Problems 23:171-92.

Kitch, Edmund W., ed. 1983. The Fire of Truth: A Remembrance of Law and Economics at Chicago 1932-1970 (a transcript of a discussion held March 21-23, 1981, in Los Angeles). Journal of Law and Economics 26:163-234.

Kline, Joseph V. 1933. Book Review: The Modern Corporation and Private Property. Columbia Law Review 33:557-60.

Kolko, Gabriel. 1963. The Triumph of Conserwatism: A Reinterpretation of American History, 1900-1916. New York: Free Press.

Laski, Harold J. 1916. The Personality of Associations. Harvard Law Review 29:404-26. . 1917. Studies in the Problem of Sovereignty. New Haven, Conn.: Yale University Press. 
1918. The Problem of Administrative Areas. Smith College Studies in History. Northampton, Mass.: Department of History at Smith College.

1925. A Grammar of Politics. New Haven, Conn.: Yale University Press.

Latham, Earl. 1952. The Group Basis of Politics: A Study in Basing-Point Legislation. Ithaca, N.Y.: Cornell University Press.

Lustig, R. Jeffrey. 1982. Corporate Liberalism: The Origins of Modern American Political Theory, 1890-1920. Berkeley and Los Angeles: University of California Press.

Manne, Henry G. 1962. The "Higher Criticism" of the Modern Corporation. Columbia Law Review 62:399-432.

Manning, Bayless. 1958. Book Review: The American Stockholder, by J. A. Livingston. Yale Law Joumal 67:1477-96.

Mark, Gregory A. 1987. The Personification of the Business Corporation in American Law. University of Chicago Law Review 54:1441-83.

Mason, Edward S., ed. 1960. The Corporation in Modern Society. Cambridge, Mass.: Harvard University Press.

McCraw, Thomas K. 1990. In Retrospect: Berle and Means. Reviews in American History. 18:578-96.

Means, Gardiner C. 1935. The Distribution of Control and Responsibility in a Modern Economy. Political Science Quarterly 50:59-69.

- 1967. Implications of the Corporate Revolution in Economic Theory. In Berle and Means 1968, xxix-xxxviii.

- 1983a. Corporate Power in the Marketplace. Joumal of Law and Economics 26:467-85.

. 1983b. Hessen's "Reappraisal." Joumal of Law and Economics 26:297-300.

Metcalf, Henry C., and L. Urwick, eds. 1942. Dynamic Administration: The Collected Papers of Mary Parker Follett. New York: Harper and Brothers.

Miller, Arthur Selwyn. 1976. The Modern Corporate State: Private Governments and the American Constitution. Westport, Conn.: Greenwood Press.

Millon, David. 1990. Theories of the Corporation. Duke Law Journal 1990:201-62.

Mills, C. Wright. 1956. The Power Elite. New York: Oxford University Press.

Mitchell, Lawrence E. 2001. Corporate Irresponsibility: America's Newest Export. New Haven, Conn: Yale University Press.

Moore, Thomas Gale. 1983. Introduction. Journal of Law and Economics 26:235-36.

Novak, William. 1996. The People's Welfare: Law and Regulation in Nineteenth-Century America. Chapel Hill: University of North Carolina Press.

O'Melinn, Liam S. 2000. The Sanctity of Association: The Corporation and Individualism in American Law. San Diego Law Review 37:101-65.

Pells, Richard H. 1989. The Liberal Mind in a Conservative Age: American Intellectuals in the 1940s and 1950s. 2nd ed. Middletown, Conn.: Wesleyan University Press.

Phillips, Michael J. 1989. Freedom in Miller's Corporate State. George Washington Law Review 57:1533-55.

Pope, James Gray. 2002. The Thirteenth Amendment versus the Commerce Clause: Labor and the Shaping of American Constitutional Law, 1921-1957. Columbia Law Review 102:1-122.

Purcell, Edward A., Jr. 1973. The Crisis of Democratic Theory: Scientific Naturalism and the Problem of Value. Lexington: University Press of Kentucky.

Reich, Charles A. 1964. The New Property. Yale Law Journal 73:733-87.

Ricardo-Campbell, Rita. 1983. Comments on the Structure of Ownership and the Theory of the Firm. Journal of Law and Economics 26:391-93.

Ripley, William Z. 1927. Main Street and Wall Street. Boston: Little, Brown, and Company. Roe, Mark. 1994. Strong Managers, Weak Owners: The Political Roots of American Corporate Finance. Princeton, N.J.: Princeton University Press. 
Rostow, Eugene V. 1960. To Whom and for What Ends Is Corporate Management Responsible? In Mason 1960, 46-71.

Sandel, Michael J. 1998. Democracy's Discontent: America in Search of Public Philosophy. Cambridge: Harvard University Press.

Schiller, Reuel E. 1999. From Group Rights to Individual Liberties: Post-War Labor Law, Liberalism, and the Waning of Union Strength. Berkeley Journal of Employment and Labor Law 20:1-73.

Schneiderman, David. 1998. Harold Laski, Viscount Haldane, and the Law of the Canadian Constitution in the Early-Twentieth Century. University of Toronto Law Journal 48:521-60.

Schwarz, Jordan A. 1987. Liberal: Adolf A. Berle and the Vision of an American Era. New York: Free Press.

Singer, Joseph W. 1988. Legal Realism Now. California Law Review 76:465-544.

Skowronek, Stephen. 1982. Building a New American State: The Emergence of National Administrative Capacities, 1877-1920. New York: Cambridge University Press.

Sommer, A. A., Jr. 1991. Whom Should the Corporation Serve? The Berle-Dodd Debate Revisited Sixty Years Later. Delaware Joumal of Corporate Law 16:33-56.

Stewart, Richard B. 1987. Organizational Jurisprudence. Harvard Law Review 101:371-90.

Stigler, George J., and Claire Friedland. 1983. The Literature of Economics: The Case of Berle and Means. Joumal of Law and Economics 26:237-68.

Tocqueville, Alexis de. 1835-40. Democracy in America. Trans. Henry Reeve. London: Saunders and Otley.

Tsuk, Dalia. 2001a. Pluralisms: The Indian New Deal as a Model. Margins: Maryland's Interdisciplinary Journal of Race, Class and Gender 1:393-449.

- 2001b. The New Deal Origins of American Legal Pluralism. Florida State University Law Review 29:189-268.

- 2002a. "A Double Runner": Felix S. Cohen and the Indian New Deal. Political and Legal Anthropology Review 25:48-68.

—. 2002b. Legal Realism. In Herbert M. Kritzer, ed., Legal Systems of the World: A Political, Social, and Cultural Encyclopedia. Santa Barbara, Calif.: ABC-CLIO.

- 2003. Corporations without Labor: The Politics of Progressive Corporate Law. University of Pennsyluania Law Review 151:1861-1912.

Veblen, Thorstein. 1923. Absentee Ownership and Business Enterprise in Recent Times. New York: B. W. Huebsch.

Warren, William C. 1964. Adolf A. Berle. Columbia Law Review 64:1377-85.

Weiner, Joseph L. 1952. The New Deal and the Corporation. University of Chicago Law Review 19:724-38.

1969. The Berle-Dodd Dialogue on the Concept of the Corporation. Columbia Law Review 64:1458-67.

Weiss, Elliott J. 1984. Economic Analysis, Corporate Law, and the ALI Corporate Governance Project. Cornell Law Review 70:1-72.

Weiss, Leonard W. 1983. The Extent and Effects of Aggregate Concentration. Joumal of Law and Economics 26:429-55.

Williamson, Oliver E. 1983. Organization Form, Residual Claimants, and Corporate Control. Joumal of Law and Economics 26:351-66.

Wilson, Woodrow. 1910. The Lawyer and the Community. A.B.A. Reporter 35: 419-39

Wormser, Maurice. 1931. Frankenstein, Incorporated. New York: McGraw-Hill Book Company, Whitrlesey House.

Wren, Daniel A. 1987. The Evolution of Management Thought. 3rd ed. New York: Wiley Series in Management.

Zeitlin, Maurice. 1974. Corporate Ownership and Control: The Large Corporation and the Capitalist Class. American Journal of Sociology 79:1073-1119. 


\section{CASES}

A. P. Smith Manufacturing Company v. Barlow, 13 N.J. 145 (1953).

Barlow v. A. P. Smith Manufacturing Company, 346 U.S. 861 (1953).

The Civil Rights Cases, 109 U.S. 3 (1883).

Dodge v. Ford, 170 N.W. 668 (1919).

Ene Railroad Co. v. Tompkins, 304 U.S. 64 (1938).

Marsh v. Alabama, 326 U.S. 501 (1946).

Shelley v. Kraemer, 334 U.S. 1 (1948).

\section{STATUTES}

National Industrial Recovery Act of 1933, Ch. 90, 48 Stat. 195.

Securities Act of 1933, Pub. L. No. 73-22, 48 Stat. 74 (codified as amended at 15 U.S.C. sections 77a-77aa (2000)).

Securities and Exchange Act of 1934, Pub. L. No. 73-291, 48 Stat. 881 (codified as amended at 15 U.S.C. sections $78 \mathrm{a}-78 \mathrm{~mm}$ (2000)).

Tennessee Valley Authority Act of 1933, Ch. 32, 48 Stat. 58. 